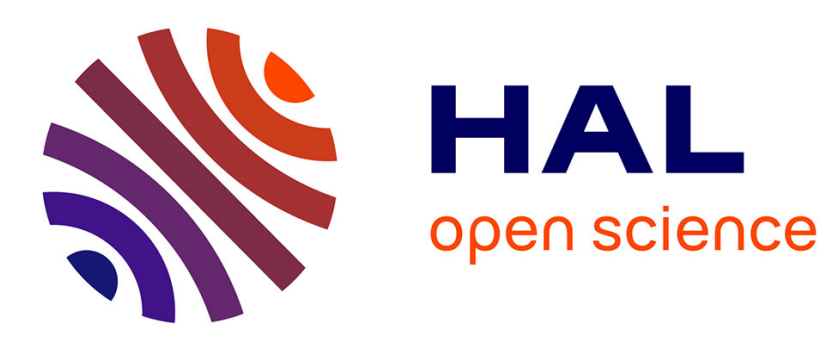

\title{
Dual Market Competition and Deposit Rate Setting in Islamic and Conventional Banks
}

Céline Meslier-Crouzille, Tastaftiyan Risfandy, Amine Tarazi

\section{To cite this version:}

Céline Meslier-Crouzille, Tastaftiyan Risfandy, Amine Tarazi. Dual Market Competition and Deposit Rate Setting in Islamic and Conventional Banks. 2016. hal-01360021

\section{HAL Id: hal-01360021 \\ https://hal-unilim.archives-ouvertes.fr/hal-01360021}

Preprint submitted on 5 Sep 2016

HAL is a multi-disciplinary open access archive for the deposit and dissemination of scientific research documents, whether they are published or not. The documents may come from teaching and research institutions in France or abroad, or from public or private research centers.
L'archive ouverte pluridisciplinaire HAL, est destinée au dépôt et à la diffusion de documents scientifiques de niveau recherche, publiés ou non, émanant des établissements d'enseignement et de recherche français ou étrangers, des laboratoires publics ou privés. 


\title{
Dual market competition and deposit rate setting in Islamic and conventional banks
}

\author{
Céline Meslier ${ }^{\mathrm{a}}$, Tastaftiyan Risfandy ${ }^{\mathrm{a}, \mathrm{b}, *}$, Amine Tarazi $^{\mathrm{a}}$ \\ ${ }^{a}$ Université de Limoges, LAPE, 5 rue Félix Eboué, 87031 Limoges Cedex, France. \\ ${ }^{b}$ Faculty of Economics and Business, Universitas Sebelas Maret, Jl. Ir. Sutami 36A, Surakarta \\ 57126, Indonesia.
}

July 15, 2016.

\begin{abstract}
This paper addresses the issue of competition in dual banking markets by analyzing the determinants of deposit rates in Islamic and conventional banks. Using a sample of 20 countries with dual banking systems over the 2000-2014 period, our results show significant differences in the drivers of Islamic and conventional banks' pricing behavior. Conventional banks with stronger market power set lower deposit rates but market power is not significant for Islamic banks. In predominantly Muslim environments, conventional banks set higher deposit rates and further higher when their market power is lower. Whereas conventional banks are influenced by the competitiveness of Islamic banks, Islamic banks are only affected by their peers in predominantly Muslim countries. Our findings have important implications regarding competition and bank stability in dual banking markets.

JEL Classifications: G21; G28
\end{abstract}

Keywords: deposit rate, competition, dual banking market, Islamic and conventional banks

* Corresponding author. Tel: +62271-647481. Fax: +62271-638143

Email: celine.meslier@ unilim.fr; tastaftiyan.risfandy@staff.uns.ac.id; amine.tarazi@unilim.fr 


\section{Introduction}

Islamic banking has substantially grown since the 2007-2008 global financial crisis. Islamic banking assets grew at an annual rate of $17.6 \%$ between 2009 and 2012 and are expected to grow at almost 20\% per year until 2018 (The Economist, 2014). Islamic banks' total assets have reached US\$ 1.9 trillion in 2014 (Hussain and Turk-Ariss, 2015) and are expected to rise to US\$2.6 trillion by 2017 (The Economist, 2013). While Islamic finance accounts for a relatively small fraction of global banking assets (less than 2\%), it has sharply increased its penetration in several countries and exceeds the threshold of $15 \%^{1}$ of total banking system assets in at least 10 countries (Iran and Sudan with a full-fledged Islamic financial sector, Bangladesh, Brunei, Kuwait, Malaysia, Qatar, Saudi Arabia, the United Arab Emirates, and Yemen) (Islamic Financial Service Board, 2015). Moreover, Islamic finance has expanded beyond Muslim countries, reaching Europe and Sub-Saharan regions. Islamic banks are present in Denmark, France, South Africa and the United Kingdom among others. How Islamic and conventional banks compete in such growing dual markets remains an insufficiently documented issue. In this work, we investigate how bank deposit rates are influenced by the concomitant presence of Islamic and conventional banks in an increasing number of countries.

The development of Islamic banking has led to an important literature investigating the potential differences between Islamic and Conventional banks in terms of profitability, risk, business models, market structure and competition (see Abedifar et al. (2015) for a survey). Nevertheless, despite the growing presence of dual banking markets, where Islamic and conventional banks operate alongside, there is a scarce literature on the impact of dual banking market structure on Islamic and conventional banks' behavior. Moreover, the results of such studies are often mixed. While Turk-Ariss (2010b) finds that Islamic banks are less competitive than their conventional counterparts, Weill (2011) does not find significant market power differences between both types of banks, in contradiction with the view that Islamic banks may benefit from captive customers. Other papers look at the macroeconomic and social implications of further penetration of Islamic banks in the financial system as a whole. Gheeraert (2014) shows that the presence of Islamic banking in Muslim countries can boost banking sector development. Abedifar

\footnotetext{
${ }^{1}$ The Islamic Financial Stability Board (IFSB) considers the Islamic financial sector as systemically important when the total Islamic banking assets account for more than $15 \%$ of the total domestic banking sector assets.
} 
et al. (2016) highlight a positive impact of the market share of Islamic banks on financial deepening and economic welfare. They also find a positive relationship between the presence of large Islamic banks and the efficiency of conventional banks in predominantly Muslim countries. Čihák and Hesse (2010) further highlight that a higher market share of Islamic banks does not alter the soundness of the other banks in a given country, suggesting that both types of banks could compete on the same market without jeopardizing financial stability.

In this work, we question how bank competition in dual markets affects the deposit rate setting behavior of Islamic banks (IBs) and conventional banks (CBs), an issue which is of great importance from both a market structure perspective and a financial stability perspective. Focusing on differences in deposit rate setting in dual markets is of particular interest due to the specific nature of Islamic banks' depositors. Islamic banks follow the Profit and Loss Sharing (PLS) principle. Transposed to banks this principle implies that profits and losses have to be shared between the borrowers and the bank and then between the bank and the depositors. Hence, the bank-depositor relationship in Islamic banking is not debt-based as in conventional banks. Islamic depositors are considered as "quasi-shareholder" and participate in bank funding through equitybased contracts, where Islamic depositors act as a source of funds and banks as a fund manager. Islamic depositors cannot claim a fixed rate of return on their deposits, a rate which will in fact depend on the bank's actual ex post profit. While Islamic banks and conventional banks are expected to set their deposit rates differently, empirical research does not report significant differences in their pricing behavior. Chong and Liu (2009) and Ito (2013) provide strong evidence that the deposit rates of Islamic and conventional banks in Malaysia are closely pegged. Investigating the deposit rates of conventional and Islamic banks in Malaysia and Turkey, Charap and Cevik (2011) show that conventional banks' deposit rates and PLS returns are cointegrated. Moreover, the authors find that conventional banks' deposit rates Granger cause returns on PLS accounts. Saraç and Zeren (2014) confirm such results and highlight a strong dependency between the deposit rates of Islamic and conventional banks in Turkey. Moreover, they also find evidence of bi-directional causality thereby highlighting more complex interactions between both types of banks than in earlier studies. While these papers provide statistical evidence of a co-evolution of deposit rates of Islamic and conventional banks, they do not investigate the determinants of deposit rates per se and to what extent they actually differ between both types of banks. 
For the purpose of our study, we consider a sample of 98 Islamic and 386 conventional banks from 20 Muslim and non-Muslim countries where Islamic and conventional banks operate alongside. We first examine the determinants of deposit rates for each type of banks (IBs and CBs) with a specific focus on the role played by market power. We analyze how both types of banks set deposit rates depending on the degree of their market power in possibly segmented markets i.e. where IBs and CBs compete for different depositors or in integrated markets i.e. where IBs and CBs compete for the same depositors. On the one hand, one might argue that both types of banks do not compete with each other and that a depositor switching from a depository institution is more likely to go to a similar type of depository institution (Adams et al., 2007; Cohen and Mazzeo, 2016). In theory, the equity-based deposit accounts offered by Islamic banks should be very different from the debt-based deposit accounts of conventional banks. Moreover, Muslims are known to be reluctant to use conventional banks financial products which are not Sharia-compliant (Abedifar et al., 2016; Beck et al., 2013). In a segmented market, banks should be only influenced by the market conditions of their own segment. On the other hand, because some studies find that IBs and CBs deposit rates are closely pegged, one might consider that IBs and CBs compete in integrated markets with the same depositors. Nevertheless, it could also be argued that while religiosity might prevent depositors from Islamic banks to switch to conventional banks, Islamic banks could well attract depositors of conventional banks if they offer higher expected returns. We hence also examine the case of a one way/asymmetric competition where CBs are influenced by IBs but not the other way round. In such a situation, conventional banks would be competing with both categories of banks, conventional and Islamic banks. We further investigate how Islamic and conventional banks react to stronger presence of Islamic banks and Muslim population. While these factors might not influence bank behavior in segmented markets, the behavior of both Islamic and conventional banks can be influenced by the importance of Muslim population and the presence of Islamic banks.

Our findings reveal notable differences in the drivers of deposit rates of Islamic banks and conventional banks. As expected, conventional banks with stronger market power set lower deposit rates but market power is not effective for Islamic banks. Moreover, conventional banks are influenced by the market conditions prevailing on the Islamic segment whereas Islamic banks are indifferent to the market structure of the conventional segment. We also find that stronger presence of Islamic banks and higher share of Islamic population are associated with higher deposit 
rates for conventional banks. Moreover, in countries with either a strong presence of Islamic banks or a high proportion of Muslim population, conventional banks set higher deposit rates which are even higher for the least competitive ones. Our results support previous findings (Abedifar et al., 2016; Baele et al., 2014; Farook et al., 2012) indicating that religious beliefs matter in dual markets and that they may well shape economic behavior.

The contribution of this paper is twofold. First, our paper complements the existing literature on bank market structure. For instance, following the deregulation process which occurred during the 2000s in the U.S., numerous studies have investigated how U.S. banks of different type, size or scope compete together. Hannan and Prager (2004) highlight differences, in deposit price behavior, between multimarket and single market banks, with significantly lower deposit rates at multi-market banks. Moreover, they also highlight a strong influence of both local market concentration and presence of multimarket banks on the pricing behavior of single-market banks. To the best of our knowledge, our paper is the first to investigate how Islamic and conventional banks compete in dual markets. We show that even though prior literature has highlighted that Islamic banks mimic conventional banks when they set their interest rates, the determinants of such rates are very different. Second, this paper also contributes to the debate on financial stability in dual markets. Increased competition can be detrimental for financial stability and among others, Hellman et al. (2000) theoretically show that deposit-rate ceilings can be necessary to prevent banks from competing through inefficiently high deposit rates possibly leading to destructive competition.

The extent to which Islamic banking development leads to more or less financial stability remains an open question. On the one hand, some papers highlight the benefits of Islamic banking development for the stability of the financial system through lower default rates on small business Islamic loans (Baele et al., 2014), better asset quality and capitalization (Beck et al., 2013), lower default risk of small Islamic banks (Abedifar et al., 2013; Čihák and Hesse, 2010), more countercyclical behavior of Islamic banks in the loan market (Ibrahim, 2016) or lower failure rate (Pappas et al., 2014). On the other hand, other papers find large Islamic banks to be less stable (Čihák and Hesse, 2010) and less diversified and less hedged (Beck et al., 2013) than large conventional banks highlighting potential instability sources. By providing evidence that conventional banks set higher rates to attract depositors in reaction to higher competitiveness of the Islamic segment, our paper 
highlights potential detrimental effects of competition, in terms of financial stability, in dual markets.

The rest of the paper is organized as follows. Section 2 presents the data, the methodology, and the descriptive statistics of our variables. Section 3 reports the empirical results and section 4 provides some further investigations and robustness tests. Section 5 concludes.

\section{Method and data}

\subsection{Econometric model}

In order to investigate the determinants of deposit rates of Islamic and conventional banks, we adopt the following econometric specification:

$$
\text { Deposit rate }_{i, t}=\alpha_{i}+\alpha_{t}+\beta_{1} \text { Lerner }_{i, t}+\varphi X_{i, t-1}+\gamma Z_{j, t}+\varepsilon_{i, t}
$$

where the $\mathrm{i}, \mathrm{j}$ and $\mathrm{t}$ subscripts refer to the individual bank, country and time dimensions respectively. $\alpha_{i}$ and $\alpha_{t}$ are respectively the individual/bank effects and time-specific effects.

Deposit rate is our dependent variable. We calculate for each Islamic and conventional bank the implicit deposit rate by considering the ratio of total interest expense on customer deposits to total customer deposits ${ }^{2}$. This proxy has been widely used in the literature to analyze deposit rate setting behavior (Hannan and Prager, 2004; Rosen, 2007). It is also the proxy which is commonly used in the deposit insurance and market discipline literature (Demirgüç-Kunt and Huizinga, 2004; Hori et al., 2009; Imai, 2006; Martinez-Peria and Schmukler, 2001; Murata and Hori, 2006). In line with the structure-performance hypothesis, a substantial literature documents that banks set a lower deposit rate in a more concentrated market (Berger and Hannan, 1989; Hannan and Berger, 1991; Nys et al., 2015; Rosen, 2007). Furthermore, we expect banks with higher market power to set a lower deposit rate.

To measure market power, we use the Lerner index (Lerner) commonly used in the bank competition literature (Berger et al., 2009; Love and Maria Soledad Martinez-Peria, 2015; Turk-

\footnotetext{
${ }^{2}$ For Islamic banks, the term "deposit return" might be more appropriate than "deposit rate" because Islamic banks do not pay interests to their depositors (see Farook et al. (2012)). However, in the rest of the paper, we use the term "deposit rate" for both Islamic and conventional banks.
} 
Ariss, 2010b; Weill, 2011). The Lerner index is defined as the markup pricing of banking products over marginal cost. We follow previous literature (Berger et al., 2009; Love and Maria Soledad Martinez-Peria, 2015; Turk-Ariss, 2010b; Weill, 2011) and use a three input cost function specification to estimate marginal cost (See Appendix A for a more detailed presentation of the computation of the Lerner index).

The coefficient $\beta_{1}$ is expected to be negative, indicating that banks with lower market power will set higher rates to attract depositors.

In order to measure the degree of competition at the country level, we construct the following three country-level Lerner indexes:

$$
\begin{aligned}
& \text { LernerI }_{j, t}=\sum_{i=1}^{n} \text { Market Share } I B_{i, I B, j, t} * \text { Lerner }_{i, t} \\
& {\text { LernerC } B_{j, t}=}^{n}=\sum_{i=1}^{n} \text { Market Share } C B_{i, C B, j, t} * \text { Lerner }_{i, t} \\
& \text { LernerMKT }_{j, t}=\sum_{i=1}^{n} \text { Market Share }_{i, j, t} * \text { Lerner }_{i, t}
\end{aligned}
$$

LernerIB $_{j t}$ and LernerCB $B_{j t}$ are computed as the weighted average of the individual Lerner indexes of respectively, the Islamic banks and the conventional banks operating in country $\mathrm{j}$ at time t. These two indexes (LernerIB $B_{j t}$ and Lerner $C B_{j t}$ ) measure the degree of competition in the Islamic and conventional banking segments respectively. We also compute a measure of competition at the country-industry level, LernerMKT $T_{j t}$, as the weighted average of the individual Lerner indexes of all banks (both Islamic and conventional banks) operating in country $\mathrm{j}$ at time $\mathrm{t}$. The latter measures the degree of market competition for the whole banking market (including both IB and CB banks). Whereas some authors rely on an simple unweighted average of individual Lerner indexes (Love and Martinez-Peria, 2015), we follow Leon (2015) and use a weighted average to take into account the relative market share of each Islamic or conventional bank either in their own market segment (IB or CB) or in the whole market (IB and CB). 
As highlighted by previous studies on Islamic banking, religious beliefs might have a significant influence on individual decisions, leading Muslim consumers to avoid banking products which are not Sharia-compliant and stay away from conventional banks (Kumru and Sarntisart, 2016). Beck et al. (2013) and Demirgüç-Kunt et al., (2013) find evidence that Muslims are less willing than non-Muslims to own formal accounts or to save their money at a formal financial institution. Islamic depositors might also be more loyal towards Islamic banks (Abedifar et al., 2016). In countries with a stronger Islamic presence, we expect that conventional banks will face more difficulties to attract consumers, especially the religious ones. Moreover, this effect might be stronger for banks having a lower market power. In order to investigate the impact of stronger Islamic presence (Islamic presence $e_{\mathrm{j}}$ ) on the deposit rate/competition nexus, we extend our baseline specification as follows:

$$
\begin{aligned}
& \text { Deposit rate }_{j, t}=\alpha_{i}+\alpha_{t}+\beta_{1} \text { Lerner }_{i, t}+\beta_{2} \text { Islamic presence }_{j, t}+\beta_{3} \text { Lerner }_{i, t} \\
& \text { Islamic presence }_{j, t}+\varphi X_{i, t-1}+\gamma Z_{j, t}+\varepsilon_{i, t}
\end{aligned}
$$

where Islamic presence is either (HighMPOP $)$ or $\left(\right.$ HighShareIB $\left._{j t}\right)$.

We use two different measures to capture the extent of Islamic presence. We follow Abedifar et al. (2016) and use the proportion of Muslim population in country $\mathrm{j}\left(M P O P_{j}\right)$. We also use the market share of Islamic banks in country $\mathrm{j}$ at time $\mathrm{t}\left(\right.$ ShareI $\left._{j t}\right)$ to investigate whether differences in Islamic bank presence might impact Islamic and conventional banks' deposit rate setting behavior. We construct two dummy variables $\left(\right.$ HighMPOP $_{j}$ and HighShareIB $\left._{j t}\right)$ that take the value of one if the share of Muslim population in country $\mathrm{j}\left(M P O P_{j}\right)$ and the market share of Islamic banks in country $\mathrm{j}$ at time $\mathrm{t}\left(\right.$ ShareI $\left._{j t}\right)$ respectively are above the sample mean and zero otherwise.

The impact of Lerner on the deposit rate is given by $\left(\beta_{1}\right)$ in countries with a low level of Islamic presence and by $\left(\beta_{1}+\beta_{3}\right)$ in countries with a high level of Islamic presence. Moreover, we also compute the impact of Islamic presence on deposit rate. Computed for different values of the Lerner index, this effect is given by $\left(\beta_{2}+\beta_{3}{ }^{*}\right.$ Lerner $\left.^{\text {ith }}\right)$ where Lerner ${ }^{\text {ith }}$ is the value of the Lerner index at either the $25^{\text {th }}$, the $50^{\text {th }}$ or the $75^{\text {th }}$ percentile.

We then consider which behavior would be consistent in either segmented or integrated market as well as markets with asymmetric competition. In segmented markets, conventional and 
Islamic banks would compete in separate markets for distinct consumers. Islamic banks would presumably set deposit rates according to the PLS principle, regardless of the importance of Muslim population or of the market share of Islamic banks in the country. Conventional banks behavior should not be altered by stronger presence of Islamic population, as conventional banks do not expect to attract this type of customers.

On the contrary, in integrated markets, where Islamic and conventional banks compete alongside for the same consumers, a higher percentage of Muslim population may lead Islamic and conventional banks to set higher deposit rates $\left(\beta_{2} \text { positive and significant }\right)^{3}$. Moreover, in countries where the market share of Islamic banks is relatively high, it might be more difficult for conventional banks to attract depositors, leading them to increase their deposit rate. Whether Islamic banks set higher/lower rates or even actually react in such an environment is unclear. Moreover, we expect the impact of stronger Islamic presence to be stronger for banks having lower market power ( $\beta_{3}$ negative). In order to attract depositors in more religious environments or in countries with a stronger presence of Islamic banks, low market power banks will need to set higher deposit rates. Eventually, in presence of asymmetric competition, Islamic banks would be insensitive to conventional banks' market power but the opposite would not be true. To prevent customers from fleeing to Islamic banks, in some circumstances conventional banks might need to adjust their deposit rates upwards ( $\beta_{3}$ negative).

We also control for a large set of bank-level $\left(\mathrm{X}_{\mathrm{it}}\right)$ characteristics. These variables are included with a one-year lag. We use the bank's return on equity (ROE) as a proxy for the PLS principle. Indeed, depositors in Islamic banks are investment account holders and they are considered as bank "quasi-shareholders". Hence, we expect a positive correlation between the return on equity and the return provided to Islamic banks' investment account holders. For conventional banks, ROE might also be considered as a proxy for profitability. We expect higher profitability to reduce default risk and hence enable banks to set a lower deposit rate. A higher ROE may therefore also be associated with a lower deposit rate (Martinez-Peria and Schmukler, 2001). We control for different dimensions of bank risk using the ratio of liquid assets to total assets (Liquidity) as a measure of liquidity risk, the ratio of loan loss reserve to total loan ( $L L R)$ to

\footnotetext{
${ }^{3}$ If Islamic and conventional banks are not viewed as very different institutions (Beck et al., 2013; Charap and Cevik, 2011; Chong and Liu, 2009; Saraç and Zeren, 2014), Islamic banks are expected to follow conventional banks in increasing their deposit rates to attract customers.
} 
proxy credit risk and the capital ratio (Equity) to proxy default risk. Highly risky banks are expected to increase their deposit rates to attract customers (Acharya and Mora, 2015; MartinezPeria and Schmukler, 2001). We also control for bank size using the logarithm of total assets (Size). Even though large and small banks might set different rates there's no clear-cut expected relationship (Rosen, 2007). Larger banks might offer higher rates to their customers because they have better investment options. However, they may also offer lower rates because they have alternative sources of funding. Listed banks are also captured by a dummy variable (Listed) which takes the value of one is the bank is listed and zero otherwise. Listed banks, which have an easier access to market funding, may be less reliant on deposits and may set lower rates than privatelyowned banks (Nys et al., 2015).

We also include in our regressions a set of country-level variables $\left(\mathrm{Z}_{\mathrm{jt}}\right)$. We control for banking market structure using the Herfindahl-Hirschman Index $(H H I)$, computed as the sum of the squared values of each bank's market share (both IBs and CBs) in the overall market. Computation of bank market share relies on banks' deposits. The value of this index lies between 0 and 1. A greater value of this index indicates a more concentrated market, which may lead banks to offer a lower deposit rate (Nys et al., 2015; Rosen, 2007). Finally, we control for macroeconomic conditions using the inflation rate (Inflation) and the growth of GDP (GGDP). Table B1 (appendix B) provides a description of all the variables used in this study.

\section{[Insert Table B1]}

We estimate Equations (1) and (2) on two distinct sub-samples, Islamic banks and conventional banks. Equation 1 is estimated using the fixed effect estimator with standard errors clustered at the bank level. For Equation 2, we rely either on the fixed-effect estimator (when HighShareIB is used as a proxy of Islamic presence) or on the Hausman-Taylor estimator (when HighMPOP is used as a proxy of Islamic presence). Indeed, as the variable HighMPOP is timeinvariant, we cannot use the fixed-effect estimator. While switching to the random effect (RE) estimator might allow us to identify all the coefficients of our equations, the Hausman test indicates that the RE estimator might be inconsistent. We hence use Hausman-Taylor (HT) estimator. The HT estimation requires the partition of the variables into endogeneous and exogeneous variables. We follow Baltagi (2005), Baltagi et al. (2003), and Bouvatier (2014) and use the the Hausman 
test (FE vs. HT) for the choice of endogenous variables. We choose the combination which maximizes the p-value of the Hausman test (FE vs. HT).

\subsection{Data and descriptive statistics}

Our empirical analysis is based on bank-level and country-level data for a sample of Islamic and conventional bank from countries with dual banking systems over the 2000-2014 period. Our bank-level data come from the Bankscope database. We use consolidated data when available and otherwise unconsolidated data. In order to deal with Islamic banking misclassification issues in the Bankscope database (Abedifar et al., 2013; Čihák and Hesse, 2010; Gheeraert, 2014), we also refer to the World Bank database of Islamic banking ${ }^{4}$. However, as the World Bank database covers not only Islamic commercial banks but also Islamic investment banks, we also check each Islamic bank's website and drop purely Islamic investment banks having no customer deposits. We winsorize our main variables at the $1 \%$ and $99 \%$ level. Our final sample includes of 2,869 observations for a set of 98 Islamic and 386 conventional banks from 20 Muslim and non-Muslim countries ${ }^{5}$. Table 1 presents some country-level information for our sample of countries.

Our country-level data come from different sources. We collect GDP growth data and inflation rates from the World Bank website and the percentage of the Muslim population comes from The World Factbook.

Table 2 provides descriptive statistics of our bank-level variables for the whole sample of banks and reports the results of mean tests between IB and CB sub-samples. Islamic banks' deposit rates are significantly lower than those of conventional banks. This finding is in line with the results of Aysan et al. (2016) who observe that Turkish Islamic banks pay lower deposit rates than their conventional counterparts. Consistent with Weill (2011), we do not find significant differences for the Lerner indexes, meaning that, on average, the market power of Islamic banks and conventional banks are not different.

\footnotetext{
${ }^{4}$ The database is available here: http://go.worldbank.org/AE0U8AYQ20

${ }^{5}$ Bahrain, Bangladesh, Egypt, Indonesia, Iraq, Jordan, Kenya, Kuwait, Malaysia, Mauritania, Pakistan, Qatar, Saudi Arabia, South Africa, Sudan, Tunisia, Turkey, United Arab Emirates, United Kingdom and Yemen.
} 
[Insert Table 2]

Conventional banks in our sample are larger (Size) than Islamic banks. Moreover, as highlighted in the literature (e.g., Abedifar et al.(2013); Beck et al. (2013)), Islamic banks are better capitalized (Equity) than Conventional banks.

Turning to country-level variables, the average market share of Islamic banks (ShareIB) is $18.3 \%$ and the average value of Muslim population $(M P O P)$ is $76.7 \%$. The mean value of $H H I$ is 0.19 .

\section{Empirical Results}

\subsection{Baseline regression}

Table 3 displays the estimation results for Equation (1) over our two sub-samples of banks. Results are reported in columns (1) to (3) for the IBs sub-sample and in columns (4) to (6) for the CBs sub-sample. As the correlation matrixes (Table B2 and B3 in Appendix B) indicate a significant correlation between our measure of bank market power (Lerner) and our PLS proxy (ROE) on both sub-samples (IBs and CBS), we first introduce Lerner and ROE separately (columns (1) and (2) for the IBs sub-sample and columns (4) and (5) for the CBs sub-sample respectively). Columns (3) and (6) report the estimation results when simultaneously including Lerner and $R O E$ for the IB and $\mathrm{CB}$ sub-samples respectively.

[Insert Table 3]

Our results show notable differences in the drivers of deposit rates in Islamic and conventional banks and specifically regarding the effect of bank market power. While higher market power (higher value of Lerner) leads conventional banks to set lower deposit interest rates, this variable is not significant for Islamic banks. In other words, contrary to conventional banks, Islamic banks, who might benefit from a captive clientele, do not set lower deposit rates when gaining market power. This result is consistent with the view that Islamic banks' behavior is shaped by the moral obligation to set a fair price to their customers, possibly limiting their willingness to

set lower prices. This result is also in line with the findings of Mollah and Zaman (2015) and 
Mollah et al. (2016) who highlight that the governance structure of Islamic banks with the presence of a Shari'ah supervisory board might play a significant role in Islamic bank behavior.

We also find a negative relationship between the deposit rate and liquidity risk for conventional banks, indicating that conventional banks set lower deposit rates when they are more liquid, although at the $10 \%$ significance level only. This result is consistent with previous findings (Martinez-Peria and Schmukler, 2001; Nys et al., 2015). However, we do not find any significant impact for Islamic banks. A positive relationship is obtained between the deposit rate and credit risk for Islamic banks, indicating that more risky banks set higher rates. Consistent with Nys et al. (2015), larger banks and listed banks set a higher deposit rate a result which holds for both Islamic and Conventional banks in our sample. As expected, we find a positive and significant effect of our PLS proxy $(R O E)$ on the deposit rates of Islamic banks, although at the $10 \%$ significance level only. Higher return to shareholders leads to an increase in the return provided to depositors. Finally, while inflation has a significant impact on deposit rates for conventional banks, regarding Islamic banks the coefficient is only significant at the $10 \%$ level.

All in all, while previous studies (e.g. Charap and Cevik (2011), Chong and Liu (2009), Saraç and Zeren (2014)) argue that the correlation between deposit rates of conventional and Islamic banks indicate that both types of finance do no significantly differ, our results provide evidence of significant differences in the way IBs and CBs set their deposit rate.

\subsection{Deposit rate, market power, and Islamic presence}

We further investigate in this section whether the pricing behavior of Islamic and conventional banks is altered by the importance of Islamic presence, measured either by the share of Muslims in the population or by the market share of Islamic banks. Table 4A presents the estimation results of Equation (2) using alternatively HighShareIB $B_{j t}$ (columns (1) and (3)) and $\operatorname{HighMPOP}_{j}$ (columns (2) and (4)) as a measure of Islamic presence. Table 4B provides the impact

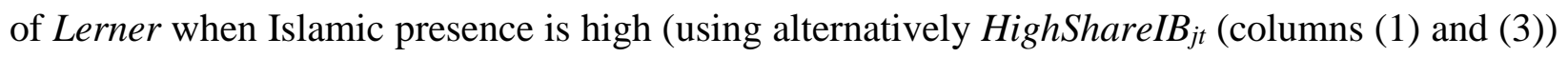
and $\operatorname{HighMPOP}_{j}$ (columns (2) and (4)) and the impact of Islamic presence (using alternatively

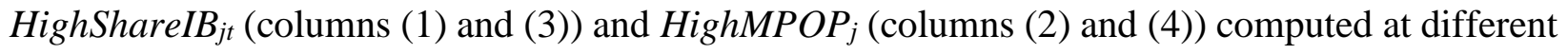
value of Lerner.

[Insert Tables 4A and 4B] 
Our findings highlight significant differences in the impact of Islamic presence on deposit rates for Islamic and conventional banks. While higher market share of Islamic banks leads to an increase in deposit rates for both types of banks, higher share of Muslim population only impacts conventional banks' pricing behavior. In countries with a predominant Muslim population, conventional banks set higher deposit rates than in countries with a lower proportion of Muslim population, while Islamic banks' pricing behavior is not impacted. This result suggests that conventional banks might face strong difficulties to attract depositors in more religious environments. Moreover, the coefficient of the interaction term (Lerner*Islamic presence) is negative and significant, indicating that the impact of Islamic presence (using both HighShareIB $B_{j t}$ and $\mathrm{HighMPOP}_{j}$ ) is stronger for conventional banks with lower market power. In countries with a predominant Muslim population or with a strong presence of Islamic banks, conventional banks set a higher deposit rate and even higher when their market power is lower.

Nevertheless, while our findings suggest that stronger market power allows Islamic banks to set higher deposit rates in countries where Islamic banks' market share is low ( $\beta_{1}$ is positive and significant), we do not find any significant impact in countries where the market share of Islamic banks is high $\left(\left(\beta_{1}+\beta_{3}\right)\right.$ is not statistically significant $)$.

Our results so far suggest significant differences in IBs and CBs pricing behavior. While conventional banks set lower deposit rates when gaining market power, we do not observe such a behavior for Islamic banks. Moreover, we also highlight that stronger presence of Islamic banks or higher proportion of Muslims in the population shapes the relationship between deposit rate and market power at conventional banks. In predominantly Islamic environments, where depositors are more reluctant to own conventional banks' financial products which are not Sharia-compliant or when Islamic banks are highly present, conventional banks face stronger difficulties to attract depositors, strengthening the impact of bank market power on deposit rates.

\subsection{Competition in dual banking market}

In this section, we investigate how both types of banks react in terms of deposit rate setting depending on the competitiveness either of the whole banking market or of each banking segment (Islamic and conventional). We address whether competition occurs in possibly segmented markets (where IBs and CBs compete for different depositors), in integrated markets (where IBs 
and CBs compete for the same depositors) or, in the case of a one way/asymmetric competition where CBs are influenced by IBs but not the other way round. We hence alternately replace the bank-level measures of market power by our different market-level competition indexes (LernerIB $_{j t}$, LernerCB $B_{j t}$, LernerMKT $T_{j t}$ ) and re-run the estimations of Equations (1) and (2). The results are presented in Tables 5, 6A and 6B. Table 5 reports the impact on IBs and CBs deposit rates of competition on the Islamic banking segment (columns (1) and (4)), on the conventional segment (columns (2) and (5)) and on the overall banking market (columns (3) and (6)).

\section{[Insert Table 5]}

Considering either the overall market (LernerMKT $T_{j t}$ ) or each separated segment (LernerIB ${ }_{j t}$, LernerCB $B_{j t}$ ), stronger competition does not alter Islamic banks' deposit rate setting behavior. On the contrary, we find a significant influence of country-level market competition on conventional banks' deposit rate setting. Stronger market-level competition leads conventional banks to set higher deposit rates. Moreover, while stronger competition within the conventional banks' segment impacts conventional banks pricing behavior, market conditions on the Islamic banks segment have no impact at all.

We further find that the importance of Islamic presence significantly alters the behavior of conventional banks. Table 6A reports the results when investigating IBs or CBs' reaction either to the competitiveness of their own segment (columns (1) and (2) and (7) and (8) respectively) or to the competitiveness of the other segment (columns (3) and (4) and (5) and (6) respectively). Table 6B provides the impact of our different market-level Lerner indexes when Islamic presence is high (using alternately HighShareIB Ht (columns (1), (3), (5) and (7)) and HighMPOP $_{j}$ (columns (2), (4),

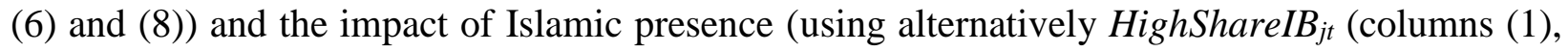
(3), (5) and (7)) and HighMPOP the Lerner index $\left(25^{\text {th }}, 50^{\text {th }}\right.$ and $75^{\text {th }}$ percentiles $)$.

[Insert Tables 6A and 6B]

Our results suggest that both Islamic and conventional banks' behavior are impacted by the market conditions of their own segment. Conventional banks set higher deposit rates when the 
degree of competition in their segment is lower, whatever the share of Muslim population or the market share of Islamic banks (column (7) and (8)). However, while the strength of Islamic presence does not alter the behavior of conventional banks, it matters for Islamic banks. We find evidence of a positive effect of competition on Islamic banks' deposit rates only in countries with a predominantly Muslim population (column (2)). We also find a negative impact of competition in the CBs' segment on IBs deposit rates, but only at the $10 \%$ level (column (4)).

Moreover, in countries with either a high share of Muslim population or a strong presence of Islamic banks, conventional banks set higher deposit rates when competition in the Islamic segment is stronger (columns (5) and (6)). Competitive conditions on the Islamic segment influence the pricing behavior of conventional banks but Islamic banks are insensitive to the conditions prevailing on the conventional segment (columns (3) and (4)). These results are consistent with the possible existence of an asymmetric competition between Islamic and conventional banks, which is dependent on the importance of Islamic presence.

The way that conventional banks set their deposit rate in response to Islamic presence is in line with previous papers highlighting the importance of religiosity in dual banking markets (Abedifar et al., 2016; Baele et al., 2014; Farook et al., 2012).

\section{Further investigations and robustness tests}

We address the impact of 2007-2009 financial crisis on deposit rate setting behavior of IBs and CBs. We construct a dummy variable Crisis which equals one during the 2007-2009 period and zero otherwise. In order to address this issue, we estimate the following equation:

Deposit rate $_{j, t}=\alpha_{i}+\alpha_{t}+\beta_{1}$ Lerner $_{i, t}+\beta_{2}$ Crisis $_{j, t}+\beta_{3}$ Lerner $_{i, t} *$ Crisis $_{j, t}+\varphi X_{i, t-1}+$ $\gamma Z_{j, t}+\varepsilon_{i, t}$

Our results (Table 7) show that IBs behavior is not impacted by the financial crisis whereas CBs set a lower deposit rate during the financial crisis and even lower when their market power is weaker.

[Insert Table 7] 
We further investigate whether the impact of market competition on deposit rates is altered by the degree of competition in the other segment. In order to capture this possible effect, we construct two dummy variables, HighLernerIB ${ }_{j t}$ and HighLernerCB $B_{j t}$ which take the value of one if the value of $L e r n e r I B_{j t}$ and the value of $L e r n e r C B_{j t}$ respectively are above the sample mean and zero otherwise. We estimate the following equations:

Deposit rate $_{j, t}^{I B}=\alpha_{i}+\alpha_{t}+\beta_{1}$ Lerner $_{j, t}^{I B}+\beta_{2}$ HighLernerC $_{j, t}+\beta_{3}$ Lerner $_{j, t}^{I B} *$

HighLernerC $B_{j, t}+\varphi X_{i, t-1}+\gamma Z_{j, t}+\varepsilon_{i, t}$

Deposit rate $_{j, t}^{C B}=\alpha_{i}+\alpha_{t}+\beta_{1}$ Lerner $_{j, t}^{C B}+\beta_{2}$ HighLernerIB $_{j, t}+\beta_{3}$ Lerner $_{j, t}^{C B} *$

HighLernerIB $B_{j, t}+\varphi X_{i, t-1}+\gamma Z_{j, t}+\varepsilon_{i, t}$

The results are provided in Table 8. While the degree of competition in the CBs segment does not influence Islamic banks' behavior, CBs deposit rates are significantly impacted by stronger competition in the IBs segment. Stronger competition in the CBs segment leads to a higher deposit rate, but only in countries where the degree of competition in the IBs segment is high $\left(\beta_{3}\right.$ is positive and significant). In other words, stronger competition in the IBs segment leads conventional banks to set higher deposit rates.

[Insert Table 8]

As highlighted by the existing literature, market interest rates significantly impact Islamic banks' behavior. In contradiction with the interest-free principle, Ergeç and Arslan (2013) find evidence of a significant influence of market interest rates on deposit rates of Islamic banks in Turkey. Caporale et al. (2016) also highlight a significant impact of interest rate shocks on Islamic bank lending even though this effect is weaker than for conventional banks. We hence include in our regressions a short term market interest rate (Interest rate). Due to the high correlation between Inflation and Interest rate, we drop the variable Inflation when including Interest rate. Short term interest rate data are taken from the International Financial Statistics database of the International 
Monetary Fund ${ }^{6}$. As highlighted in the existing literature, we find a positive and significant impact of market interest rates on deposit rates for both IBs and CBs. We still find conventional banks to set higher deposit rates when their market power is lower and even lower in predominantly Islamic environment $\left(\left(\beta_{1}+\beta_{3}\right)\right.$ is negative and significant) (Tables 9A and 9B).

[Insert Tables 9A and 9B]

We also conduct some robustness tests. We replace the return on equity $(R O E)$ by the return on assets (ROA). Our main results remain identical (Tables 10A and 10B).

[Insert Tables 10A and 10B]

Following Rosen (2007) who argues that the presence of ROE in such models may lead to endogeneity issues, we also conduct our regressions by using the instrumental variables technique. One year lagged ROE is instrumented by two-year lagged ROE, ROE Industry, and market development (the ratio of stock market capitalization to GDP per capita). The Kleibergen-Paap FStatistics indicates that the instruments we use are strong. The non-significant value of the Hansen J-Statistics (over-identification test) indicates that our instruments are not correlated with the error term. Using IV leaves our main results unchanged (Table 11).

[Insert Table 11]

\section{Conclusion}

This paper investigates the impact of competition in dual banking markets and focuses on differences in deposit rate setting in Islamic and conventional banks. While, in theory, the specific nature of deposit accounts at Islamic banks should lead to significant differences compared with conventional banks' deposits the literature has so far argued that Islamic and conventional banks deposit rates are closely pegged. We show that there are nevertheless notable differences in the

\footnotetext{
${ }^{6}$ Out of the 20 countries of our sample, there are two countries (Sudan and United Arab Emirates) for which short term interest rate data are not available over our sample period.
} 
determinants of deposit rates in the two types of institutions. Market power measured at the individual bank level by the Lerner index is only significant for conventional banks. Moreover, in predominantly Muslim countries or in countries with an important presence of Islamic banks, conventional banks set higher deposit rates and such rates are even higher for conventional banks with relatively lower market power. In such environments, conventional banks presumably face stronger difficulties to attract depositors, strengthening thereby the impact of competition. We further find that the conventional banks are sensitive to deposit rates offered by Islamic banks, while Islamic banks are only influenced by their peers and mostly in predominantly Muslim countries.

Our findings have important implications for the future of banking in dual markets where conventional and Islamic banks operate alongside and specifically in countries where Islamic banks are persistently gaining market shares. Moreover, because conventional banks are found to significantly react to stronger competition from Islamic banks, bank regulators and supervisors should carefully monitor both types of institutions in such dual markets to prevent possibly excessive competition from jeopardizing financial stability.

\section{References}

Abedifar, P., Ebrahim, S.M., Molyneux, P., Tarazi, A., 2015. Islamic Banking and Finance: Recent Empirical Literature and Directions for Future Research. J. Econ. Surv. 29, 637-670. doi:10.1111/joes.12113

Abedifar, P., Hasan, I., Tarazi, A., 2016. Finance-Growth Nexus and Dual-Banking Systems: Relative Importance of Islamic Banks. J. Econ. Behav. Organ. 1-18. doi:10.2139/ssrn.2614180

Abedifar, P., Molyneux, P., Tarazi, A., 2013. Risk in Islamic Banking. Rev. Financ. 17, 20352096. doi:10.1093/rof/rfs041

Adams, R.M., Brevoors, K.P., Kiser, E.K., 2007. Who Competes with Whom? The Case of Depository Institutions. J. Ind. Econ. 55, 141-167.

Aysan, A.F., Disli, M., Duygun, M., Ozturk, H., 2016. Islamic Banks, Deposit Insurance Reform, and Market Discipline: Evidence from a Natural Framework. J. Financ. Serv. Res. 1-26. doi:10.1007/s10693-016-0248-z 
Baele, L., Farooq, M., Ongena, S., 2014. Of religion and redemption: Evidence from default on Islamic loans. J. Bank. Financ. 44, 141-159. doi:10.1016/j.jbankfin.2014.03.005

Baltagi, B.H., 2005. Econometric analysis of panel data, John Wiley \& Sons Ltd.

Baltagi, B.H., Bresson, G., Pirotte, A., 2003. Fixed effects, random effects or Hausman-Taylor? Econ. Lett. 79, 361-369. doi:10.1016/S0165-1765(03)00007-7

Beck, T., Demirgüç-Kunt, A., Merrouche, O., 2013. Islamic vs. conventional banking: Business model, efficiency and stability. J. Bank. Financ. 37, 433-447. doi:10.1016/j.jbankfin.2012.09.016

Berger, A.N., Hannan, T.H., 1989. Price-Concentration Relationship in Banking. Rev. Econ. Stat. 71, 291-299.

Berger, A.N., Klapper, L.F., Turk-Ariss, R., 2009. Bank Competition and Financial Stability. J. Financ. Serv. Res. 35, 99-118. doi:10.1007/s 10693-008-0050-7

Bouvatier, V., 2014. Heterogeneous bank regulatory standards and the cross-border supply of financial services. Econ. Model. 40, 342-354. doi:10.1016/j.econmod.2014.04.013

Caporale, G.M., Çatık, A.N., Helmi, M.H., Ali, F.M., Tajik, M., 2016. The Bank Lending Channel in a Dual Banking System : Evidence from Malaysia, SSRN Working Paper.

Charap, J., Cevik, S., 2011. The Behavior of Conventional and Islamic Bank Deposit Returns in Malaysia and Turkey. IMF Work. Pap. 11, 1. doi:10.5089/9781455293704.001

Chong, B.S., Liu, M.-H., 2009. Islamic banking: Interest-free or interest-based? Pacific-Basin Financ. J. 17, 125-144. doi:10.1016/j.pacfin.2007.12.003

Čihák, M., Hesse, H., 2010. Islamic Banks and Financial Stability: An Empirical Analysis. J. Financ. Serv. Res. 38, 95-113. doi:10.1007/s10693-010-0089-0

Cohen, A.M., Mazzeo, M.J., 2016. Market Structure and Competition among Retail Depository Institutions. Rev. Econ. Stat. 89, 60-74.

Demirgüç-Kunt, A., Huizinga, H., 2004. Market discipline and deposit insurance. J. Monet. Econ. 51, 375-399. doi:10.1016/j.jmoneco.2003.04.001

Demirgüç-Kunt, A., Klapper, L.F., Randall, D., 2013. Islamic finance and financial inclusion: Measuring use and demand for formal financial services among muslim adults (No. 6642), World Bank Policy Research Working Paper.

Ergeç, E.H., Arslan, B.G., 2013. Impact of interest rates on Islamic and conventional banks: the case of Turkey. Appl. Econ. 45, 2381-2388. doi:10.1080/00036846.2012.665598 
Farook, S., Hassan, M.K., Clinch, G., 2012. Profit distribution management by Islamic banks: An empirical investigation. Q. Rev. Econ. Financ. 52, 333-347. doi:10.1016/j.qref.2012.04.007

Gheeraert, L., 2014. Does Islamic finance spur banking sector development? J. Econ. Behav. Organ. 103, S4-S20. doi:10.1016/j.jebo.2014.02.013

Hannan, T.H., Berger, A.N., 1991. The Rigidity of Prices: Evidence from the Banking Industry. Am. Econ. Rev. 81, 938-945.

Hannan, T.H., Prager, R.A., 2004. The competitive implications of multimarket bank branching. J. Bank. Financ. 28, 1889-1914. doi:10.1016/j.jbankfin.2003.06.006

Hori, M., Ito, Y., Murata, K., 2009. Do Depositors Respond Rationally To Bank Risks? Evidence From Japanese Banks During Crises. Pacific Econ. Rev. 14, 581-592. doi:10.1111/j.14680106.2009.00470.x

Hussain, M., Turk-Ariss, R., 2015. An overview of Islamic finance (No. WP/15/120), IMF Working Paper.

Imai, M., 2006. Market discipline and deposit insurance reform in Japan. J. Bank. Financ. 30, 3433-3452. doi:10.1016/j.jbankfin.2006.01.009

Islamic Financial Service Board, 2015. Islamic Financial Service Industry Stability Report.

Ito, T., 2013. Islamic rates of return and conventional interest rates in the Malaysian deposit market. Int. J. Islam. Middle East. Financ. Manag. Vol. 6, pp. 290 - 303. doi:10.1108/IMEFM-11-2012-0113

Kumru, C.S., Sarntisart, S., 2016. Banking for those unwilling to bank: Implications of Islamic banking systems. Econ. Model. 54, 1-12. doi:10.1016/j.econmod.2015.12.011

Leon, F., 2015. Does bank competition alleviate credit constraints in developing countries? J. Bank. Financ. 57, 130-142. doi:10.1016/j.jbankfin.2015.04.005

Love, I., Martinez-Peria, M.S., 2015. How bank competition affects firms' access to finance, World Bank Economic Review. doi:10.1093/wber/lhu003

Martinez-Peria, M.P., Schmukler, S.L., 2001. Do depositors punish bank for bad behavior? J. Finance 56, 1029-1051.

Mollah, S., Hassan, M.K., Al Farooque, O., Mobarek, A., 2016. The governance, risk-taking, and performance of Islamic banks. J. Financ. Serv. Res. 1-25. doi:10.1007/s10693-016-0245-2

Mollah, S., Zaman, M., 2015. Shari'ah supervision, corporate governance and performance: Conventional vs. Islamic banks. J. Bank. Financ. 58, 418-435. 
doi:10.1016/j.jbankfin.2015.04.030

Murata, K., Hori, M., 2006. Do small depositors exit from bad banks? Evidence from small financial institutions in Japan. Japanese Econ. Rev. 57, 260-278. doi:10.1111/j.14685876.2006.00363.x

Nys, E., Tarazi, A., Trinugroho, I., 2015. Political connections, bank deposits, and formal deposit insurance. J. Financ. Stab. 19, 83-104. doi:10.1016/j.jfs.2015.01.004

Rosen, R.J., 2007. Banking market conditions and deposit interest rates. J. Bank. Financ. 31, 38623884. doi:10.1016/j.jbankfin.2007.02.009

Saraç, M., Zeren, F., 2014. The dependency of Islamic bank rates on conventional bank interest rates: further evidence from Turkey. Appl. Econ. 47, 669-679. doi:10.1080/00036846.2014.978076

Soedarmono, W., Machrouh, F., Tarazi, A., 2011. Bank market power, economic growth and financial stability: Evidence from Asian banks. J. Asian Econ. 22, 460-470. doi:10.1016/j.asieco.2011.08.003

The Economist, 2014. Big interest, no interest [WWW Document]. Econ. URL http://www.economist.com/news/finance-and-economics/21617014-market-islamicfinancial-products-growing-fast-big-interest-no-interest

The Economist, 2013. A mecca for sukuk [WWW Document]. Econ. URL http://www.economist.com/blogs/schumpeter/2013/11/islamic-finance

Turk-Ariss, R., 2010a. Competitive conditions in Islamic and conventional banking: A global perspective. Rev. Financ. Econ. 19, 101-108. doi:10.1016/j.rfe.2010.03.002

Turk-Ariss, R., 2010b. On the implications of market power in banking: Evidence from developing countries. J. Bank. Financ. 34, 765-775. doi:10.1016/j.jbankfin.2009.09.004

Weill, L., 2011. Do Islamic Banks Have Greater Market Power? Comp. Econ. Stud. 53, 291-306. doi:10.1057/ces.2011.1 
APPENDIX A: Lerner index computation

The Lerner index we compute here is consistent with Berger et al. (2009), Love and Martinez-Peria (2015), Turk-Ariss (2010) and Weill (2011). Total cost is estimated using the following trans-logarithm cost function:

$$
\begin{aligned}
\ln (\mathrm{TC})=\propto_{0}+ & \propto_{1} \ln (\mathrm{TA})+\frac{1}{2} \propto_{2}(\ln \mathrm{TA})^{2}+\sum_{\mathrm{j}=1}^{3} \beta_{\mathrm{j}} \ln \left(\mathrm{W}_{\mathrm{j}}\right)+\sum_{\mathrm{j}=1}^{3} \sum_{\mathrm{k}=1}^{3} \beta_{\mathrm{jk}} \ln \left(\mathrm{W}_{\mathrm{j}}\right) \ln \left(\mathrm{W}_{\mathrm{k}}\right) \\
& +\sum_{\mathrm{j}=1}^{3} \gamma_{\mathrm{j}} \ln (\mathrm{TA}) \ln \left(\mathrm{W}_{\mathrm{j}}\right)+\varepsilon
\end{aligned}
$$

TC denotes total costs (sum of total interest expenses and total non-interest expenses) and TA is total assets. We use three input prices: (1) price of labor, $\mathrm{W}_{1}$; price of capital, $\mathrm{W}_{2}$; and price of funds, $\mathrm{W}_{3}$. The price of labor is calculated by dividing personnel expenses to total assets. The price of capital is computed by calculating the ratio of other operating expenses to total assets. The price of funding is the ratio of interest expenses to total customer deposits. After we obtain all the coefficients from the cost function, we compute marginal cost by using equation (ii) as follows.

$$
\begin{aligned}
& \mathrm{MC}=\frac{\mathrm{TC}}{\mathrm{TA}}\left(\propto_{1}+\propto_{2} \ln (\mathrm{TA})+\sum_{\mathrm{j}=1}^{3} \gamma_{\mathrm{j}} \ln \left(\mathrm{W}_{\mathrm{j}}\right)\right) \\
& \text { Lerner }_{\mathrm{it}}=\frac{\text { Price }_{\mathrm{it}}-\mathrm{MC}_{\mathrm{it}}}{\text { Price }_{\mathrm{it}}}
\end{aligned}
$$

After we get all of the coefficients, we compute marginal costs as in equation (ii). Finally, the bank level Lerner index can be calculated using equation (iii). The Lerner index summarizes the differences between price of product and marginal costs, scaled by price. Price itself is the ratio of total revenue (sum of total interest income and total non-interest operating income) to total assets. Generally speaking, a higher value of the Lerner index indicates higher market power or lower market competition because banks are able to set the price above the marginal cost in less competitive markets. The value of the Lerner index ranges between 0 (high market power/lowly competitive market) and 1 (low market power/highly competitive market). However, the Lerner index can also be negative for inefficient banks (Soedarmono et al., 2011). 


\section{APPENDIX B}

Table B1. Summary of the variable definition

\begin{tabular}{|c|c|c|}
\hline & Variables description & Source \\
\hline \multicolumn{3}{|c|}{ Bank-level variables } \\
\hline Deposit rate $_{i t}$ & The ratio of total interest expense on deposits to consumer deposits. & Bankscope \\
\hline Lerner $_{i t}$ & Bank-level Lerner index. & Bankscope \\
\hline$R O E_{i t}$ & The ratio of equity to total assets. & Bankscope \\
\hline Liquidity $_{i t}$ & The ratio of liquid assets to total assets. & Bankscope \\
\hline$R O A_{i t}$ & The ratio of net income to total assets. & \\
\hline Equity $_{i t}$ & The ratio of equity capital to total asset. & Bankscope \\
\hline Size $_{i t}$ & The logarithm of total assets. & Bankscope \\
\hline$L L R_{i t}$ & The ratio of non-performing loans to gross loans. & Bankscope \\
\hline Listed & A dummy variable that takes the value of one if the bank is listed and zero otherwise & Bankscope \\
\hline \multicolumn{3}{|c|}{ Country-level variables } \\
\hline LernerIB $B_{j t}$ & $\begin{array}{l}\text { The weighted average of the individual Lerner indexes of Islamic banks in country } \\
\mathrm{j} \text { at time t. }\end{array}$ & Bankscope \\
\hline LernerCB $B_{j t}$ & $\begin{array}{l}\text { The weighted average of the individual Lerner indexes of conventional banks in } \\
\text { country } \mathrm{j} \text { at time } \mathrm{t} \text {. }\end{array}$ & Bankscope \\
\hline LernerMKT $T_{j t}$ & $\begin{array}{l}\text { The weighted average of the individual Lerner indexes of all banks (both Islamic } \\
\text { and conventional banks) operating in country } \mathrm{j} \text { at time } \mathrm{t} \text {. }\end{array}$ & Bankscope \\
\hline ShareIB $_{j t}$ & Market share of Islamic banks (in terms of total deposits) in country $j$ at time $t$. & Bankscope \\
\hline HighShareIB $B_{j t}$ & $\begin{array}{l}\text { A dummy variable that takes the value of one if the value of ShareIB } B_{j t} \text { is above the } \\
\text { sample mean and zero otherwise. }\end{array}$ & Bankscope \\
\hline$M P O P_{j}$ & Proportion of Muslims in country j. & $\begin{array}{l}\text { The World } \\
\text { Factbook }\end{array}$ \\
\hline $\operatorname{HighMPOP}_{j}$ & $\begin{array}{l}\text { A dummy variable that takes the value of one if the value of } M P O P_{j} \text { is above the } \\
\text { sample mean and zero otherwise }\end{array}$ & $\begin{array}{l}\text { World } \\
\text { Factbook }\end{array}$ \\
\hline Inflation $_{j t}$ & Rate of inflation & $\begin{array}{l}\text { The World } \\
\text { Bank website. }\end{array}$ \\
\hline$G G D P_{j t}$ & GDP growth & $\begin{array}{l}\text { The World } \\
\text { Bank website. }\end{array}$ \\
\hline$H H I_{j t}$ & $\begin{array}{l}\text { Hirschman-Herfindahl index }(\mathrm{HHI}) \text { is a proxy for market concentration in country } \\
\mathrm{j} \text { at date } \mathrm{t}: H H I_{j, t}=\sum_{i=1}^{n}\left(\text { Total_Assets }_{i, j, t} / \sum_{i=1}^{n} \text { Total_Assets }_{i, j, t}\right)^{2} \text {. The value } \\
\text { ranges between } 0 \text { and } 1 \text {. Higher values indicate that the market is more } \\
\text { concentrated. }\end{array}$ & Bankscope \\
\hline Interest rates jt & Short-term interest rate & $\begin{array}{l}\text { International } \\
\text { Financial } \\
\text { Statistics } \\
\text { (website of } \\
\text { IMF) }\end{array}$ \\
\hline
\end{tabular}


Table B2. Correlation matrix of Islamic banks' sub-sample

\begin{tabular}{|c|c|c|c|c|c|c|c|c|c|c|c|c|c|c|c|c|c|}
\hline & $\begin{array}{l}\text { Deposit } \\
\text { rate }\end{array}$ & Lerner & LernerIB & LernerCB & LernerMKT & HighShareIB & HighMPOP & ROE & Liquidity & LLR & Equity & Size & ROA & Listed & Inflation & HHI & GGDP \\
\hline Deposit rate & 1.000 & & & & & & & & & & & & & & & & \\
\hline Lerner & -0.151 & 1.000 & & & & & & & & & & & & & & & \\
\hline LernerIB & -0.117 & 0.637 & 1.000 & & & & & & & & & & & & & & \\
\hline LernerCB & -0.428 & 0.447 & 0.586 & 1.000 & & & & & & & & & & & & & \\
\hline LernerMKT & -0.407 & 0.462 & 0.635 & 0.984 & 1.000 & & & & & & & & & & & & \\
\hline HighShareIB & -0.080 & 0.116 & 0.353 & 0.364 & 0.342 & 1.000 & & & & & & & & & & & \\
\hline HighMPOP & 0.263 & 0.196 & 0.475 & 0.209 & 0.247 & 0.214 & 1.000 & & & & & & & & & & \\
\hline Liquidity & -0.152 & -0.275 & -0.321 & 0.016 & 0.003 & -0.182 & -0.273 & -0.327 & 1.000 & & & & & & & & \\
\hline LLR & 0.100 & -0.216 & -0.256 & -0.177 & -0.190 & -0.044 & 0.058 & -0.298 & 0.197 & 1.000 & & & & & & & \\
\hline Equity & 0.137 & -0.067 & 0.052 & 0.221 & 0.229 & 0.080 & 0.133 & -0.106 & 0.236 & 0.063 & 1.000 & & & & & & \\
\hline Size & -0.351 & 0.520 & 0.424 & 0.451 & 0.446 & 0.268 & 0.108 & 0.327 & -0.288 & -0.172 & -0.252 & 1.000 & & & & & \\
\hline ROA & 0.115 & 0.606 & 0.516 & 0.220 & 0.254 & 0.096 & 0.235 & 0.642 & -0.232 & -0.334 & 0.127 & 0.342 & 1.000 & & & & \\
\hline Listed & 0.103 & 0.040 & 0.024 & -0.026 & -0.005 & -0.251 & 0.008 & 0.065 & 0.261 & -0.026 & 0.157 & -0.171 & 0.107 & 1.000 & & & \\
\hline Inflation & 0.247 & -0.054 & 0.069 & -0.101 & -0.096 & 0.030 & 0.326 & 0.058 & 0.040 & 0.067 & 0.074 & -0.156 & 0.074 & 0.275 & 1.000 & & \\
\hline HHI & 0.007 & 0.232 & 0.229 & 0.247 & 0.261 & -0.093 & 0.199 & 0.002 & 0.130 & 0.117 & 0.320 & -0.103 & 0.198 & 0.115 & 0.059 & 1.000 & \\
\hline Interest & 0.441 & -0.177 & -0.088 & -0.483 & -0.470 & -0.002 & 0.406 & 0.002 & -0.150 & 0.110 & -0.117 & -0.413 & -0.069 & 0.019 & 0.406 & -0.115 & -0.034 \\
\hline
\end{tabular}


Table B3. Correlation matrix of conventional banks' sub-sample.

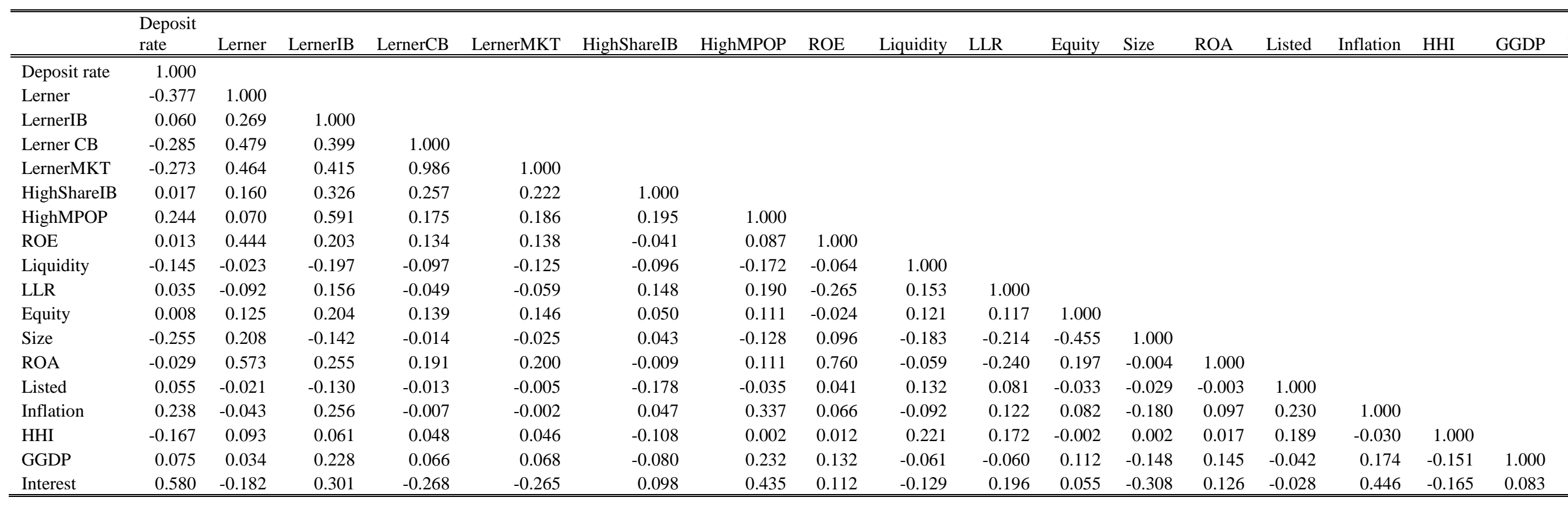


Table 1. Banking sector structure in sample countries

\begin{tabular}{|c|c|c|c|c|c|c|c|c|c|c|}
\hline Country & IB & $\mathrm{CB}$ & ShareIB $(\%)$ & MPOP $(\%)$ & LernerIB & LernerCB & LernerMKT & Inflation & GGDP & $\mathrm{HHI}$ \\
\hline Bahrain & 6 & 9 & 20.80 & 70.30 & 0.230 & 0.248 & 0.239 & 0.066 & -0.002 & 0.188 \\
\hline Bangladesh & 7 & 33 & 16.39 & 89.50 & 0.195 & 0.164 & 0.171 & 0.059 & 0.043 & 0.114 \\
\hline Egypt & 3 & 21 & 6.53 & 90.00 & 0.139 & 0.118 & 0.119 & 0.088 & 0.022 & 0.149 \\
\hline Indonesia & 7 & 66 & 1.30 & 87.20 & 0.139 & 0.261 & 0.259 & 0.105 & 0.040 & 0.102 \\
\hline Iraq & 1 & 5 & 24.30 & 99.00 & 0.311 & 0.260 & 0.261 & 0.116 & 0.023 & 0.361 \\
\hline Jordan & 3 & 10 & 7.52 & 97.20 & 0.246 & 0.271 & 0.270 & 0.050 & 0.029 & 0.389 \\
\hline Kenya & 2 & 30 & 0.80 & 11.10 & 0.063 & 0.309 & 0.308 & 0.080 & 0.017 & 0.117 \\
\hline Kuwait & 5 & 5 & 39.02 & 76.70 & 0.325 & 0.491 & 0.426 & 0.082 & -0.002 & 0.193 \\
\hline Malaysia & 19 & 28 & 12.68 & 61.30 & 0.190 & 0.309 & 0.300 & 0.036 & 0.033 & 0.093 \\
\hline Mauritania & 1 & 3 & 14.09 & 100.00 & 0.337 & 0.264 & 0.254 & 0.069 & 0.020 & 0.191 \\
\hline Pakistan & 9 & 23 & 14.70 & 96.40 & 0.254 & 0.220 & 0.224 & 0.110 & 0.020 & 0.151 \\
\hline Qatar & 5 & 6 & 16.05 & 77.50 & 0.533 & 0.464 & 0.472 & 0.080 & 0.016 & 0.279 \\
\hline Saudi Arabia & 5 & 7 & 38.41 & 99.00 & 0.463 & 0.524 & 0.500 & 0.058 & 0.025 & 0.116 \\
\hline South Africa & 1 & 16 & 0.14 & 1.50 & 0.086 & 0.205 & 0.205 & 0.072 & 0.016 & 0.298 \\
\hline Sudan & 4 & 1 & 72.06 & 99.00 & 0.159 & 0.239 & 0.216 & 0.148 & 0.040 & 0.335 \\
\hline Tunisia & 1 & 10 & 6.96 & 99.10 & 0.262 & 0.280 & 0.288 & 0.036 & 0.026 & 0.149 \\
\hline Turkey & 4 & 26 & 4.27 & 99.80 & 0.199 & 0.099 & 0.100 & 0.167 & 0.030 & 0.167 \\
\hline United Arab Emirates & 10 & 17 & 17.35 & 76.00 & 0.322 & 0.456 & 0.433 & 0.065 & -0.028 & 0.102 \\
\hline United Kingdom & 3 & 66 & 0.01 & 4.40 & -0.552 & 0.211 & 0.211 & 0.023 & 0.012 & 0.127 \\
\hline Yemen & 2 & 4 & 28.04 & 99.10 & 0.325 & 0.337 & 0.213 & 0.119 & -0.002 & 0.268 \\
\hline Total & 98 & 386 & & & & & & & & \\
\hline Average & & & 18.27 & 76.71 & 0.231 & 0.291 & 0.278 & 0.082 & 0.019 & 0.194 \\
\hline
\end{tabular}

Table 2. Descriptive statistics

\begin{tabular}{|c|c|c|c|c|c|c|c|c|c|c|c|c|}
\hline \multirow[b]{2}{*}{ Variable } & \multicolumn{5}{|c|}{ All sample } & \multicolumn{3}{|c|}{ Islamic banks } & \multicolumn{3}{|c|}{ Conventional banks } & \multirow{2}{*}{ Diff. } \\
\hline & Obs. & Mean & S.D. & Min & Max & Obs. & Mean & S.D. & Obs. & Mean & S.D. & \\
\hline Deposit rate & 2,869 & 0.042 & 0.034 & 0.000 & 0.245 & 525 & 0.038 & 0.035 & 2,344 & 0.042 & 0.033 & $-2.482 * *$ \\
\hline Lerner & 2,779 & 0.252 & 0.215 & -0.751 & 0.694 & 499 & 0.245 & 0.251 & 2,280 & 0.254 & 0.207 & -0.845 \\
\hline ROE & 2,869 & 0.100 & 0.137 & -0.702 & 0.535 & 525 & 0.091 & 0.130 & 2,344 & 0.102 & 0.138 & -1.668 \\
\hline Liquidity & 2,868 & 0.246 & 0.159 & 0.060 & 0.790 & 525 & 0.240 & 0.143 & 2,343 & 0.247 & 0.162 & -0.914 \\
\hline LLR & 2,841 & 0.051 & 0.065 & 0.001 & 0.460 & 518 & 0.050 & 0.072 & 2,323 & 0.051 & 0.064 & -0.314 \\
\hline Equity & 2,869 & 0.124 & 0.070 & 0.037 & 0.501 & 525 & 0.137 & 0.090 & 2,344 & 0.121 & 0.064 & $4.769 * * *$ \\
\hline Size & 2,869 & 22,400 & 67,400 & 16.361 & 436,000 & 525 & 7,752 & 14,200 & 2,344 & 25,700 & 73,900 & $-5.541 * * *$ \\
\hline Listed & 2,869 & 0.646 & 0.478 & 0.000 & 1.000 & 525 & 0.604 & 0.490 & 2,344 & 0.655 & 0.476 & $-2.207 * * *$ \\
\hline
\end{tabular}

Note: The last column reports t-statistics of mean equality test between Islamic and conventional banks. $* * *$ and $* *$ indicate significance at $1 \%$ and $5 \%$ respectively. 
Table 3. Determinants of Islamic and conventional banks' deposit rate setting behavior

This table displays the estimation results of Equation (1) for two sub-samples, Islamic banks (columns (1) to (3)) and conventional banks (columns (4) to (6)):

Deposit rate $_{i, t}=\alpha_{i}+\alpha_{t}+\beta_{1}$ Lerner $_{i, t}+\varphi X_{i, t-1}+\gamma Z_{j, t}+\varepsilon_{i, t}$

where Deposit rate it is our dependent variable, Lerner $i$, is our measure of banks' market power, $X_{\text {it- } 1}$ is a vector of one-year lagged bank-level variables and $Z_{j t}$ a vector of country-level variables. See Table B1 for variable definitions.

We employ the fixed-effect technique for our estimation. Standard errors are clustered at the bank level. Robust t-statistics are reported in parentheses. $* * *, * *$, and $*$ indicate significance at $1 \%, 5 \%$, and $10 \%$ respectively.

\begin{tabular}{|c|c|c|c|c|c|c|}
\hline & \multicolumn{3}{|c|}{ Islamic banks } & \multicolumn{3}{|c|}{ Conventional banks } \\
\hline & (1) & (2) & (3) & (4) & (5) & (6) \\
\hline \multirow[t]{2}{*}{ Lerner } & 0.0142 & & 0.0118 & $-0.0371 * * *$ & & $-0.0386 * * *$ \\
\hline & $(0.75)$ & & $(0.60)$ & $(-5.34)$ & & $(-5.48)$ \\
\hline \multirow[t]{2}{*}{ ROE } & & $0.0280 * *$ & $0.0219 *$ & & 0.000201 & 0.00763 \\
\hline & & $(2.07)$ & $(1.67)$ & & $(0.04)$ & (1.49) \\
\hline \multirow[t]{2}{*}{ Liquidity } & -0.00232 & 0.00352 & -0.0000320 & $-0.0139 *$ & $-0.0147 *$ & $-0.0140 *$ \\
\hline & $(-0.16)$ & $(0.27)$ & $(-0.00)$ & $(-1.81)$ & $(-1.78)$ & $(-1.84)$ \\
\hline \multirow[t]{2}{*}{ LLR } & 0.108 & $0.132 * *$ & $0.117^{*}$ & $-0.0329 *$ & -0.0271 & -0.0288 \\
\hline & (1.65) & $(2.21)$ & (1.73) & $(-1.86)$ & $(-1.54)$ & $(-1.62)$ \\
\hline \multirow[t]{2}{*}{ Equity } & 0.0659 & 0.0601 & 0.0634 & -0.00994 & -0.0192 & -0.0119 \\
\hline & $(1.37)$ & $(1.35)$ & $(1.37)$ & $(-0.34)$ & $(-0.61)$ & $(-0.40)$ \\
\hline \multirow[t]{2}{*}{ Size } & $0.0152 * *$ & $0.0127 * *$ & $0.0132 * *$ & $0.00988 * * *$ & $0.0100 * * *$ & $0.00963 * * *$ \\
\hline & $(2.34)$ & $(2.00)$ & $(2.07)$ & $(4.63)$ & $(4.18)$ & $(4.48)$ \\
\hline \multirow[t]{2}{*}{ Listed } & 0.00683 & 0.00232 & $0.0437 * * *$ & $0.0533 * * *$ & $0.0568 * * *$ & $0.0523 * * *$ \\
\hline & (1.63) & $(0.76)$ & $(2.75)$ & (7.35) & $(7.95)$ & (7.03) \\
\hline \multirow[t]{2}{*}{ Inflation } & $0.0303 *$ & 0.0155 & $0.0293^{*}$ & $0.0168 * * *$ & $0.0161 * *$ & $0.0166 * * *$ \\
\hline & (1.88) & $(0.91)$ & $(1.78)$ & $(3.10)$ & $(2.43)$ & $(3.06)$ \\
\hline \multirow[t]{2}{*}{ HHI } & 0.0887 & 0.0945 & 0.0921 & $-0.0443 *$ & -0.0241 & $-0.0447 * *$ \\
\hline & $(1.22)$ & $(1.25)$ & $(1.25)$ & $(-1.95)$ & $(-0.84)$ & $(-1.99)$ \\
\hline \multirow[t]{2}{*}{ GGDP } & -0.00714 & -0.00155 & -0.00940 & -0.0198 & $-0.0279 * *$ & $-0.0210 *$ \\
\hline & $(-0.31)$ & $(-0.07)$ & $(-0.41)$ & $(-1.63)$ & $(-2.13)$ & $(-1.71)$ \\
\hline \multirow[t]{2}{*}{ Constant } & $-0.231 * *$ & $-0.188^{*}$ & $-0.197 *$ & $-0.0963 * * *$ & $-0.109 * * *$ & $-0.0924 * * *$ \\
\hline & $(-2.04)$ & $(-1.74)$ & $(-1.82)$ & $(-2.77)$ & $(-2.85)$ & $(-2.64)$ \\
\hline Time effects & Yes & Yes & Yes & Yes & Yes & Yes \\
\hline N Obs. & 500 & 525 & 499 & 2281 & 2344 & 2280 \\
\hline N Banks. & 96 & 98 & 96 & 380 & 386 & 380 \\
\hline R-Squared & 0.240 & 0.229 & 0.247 & 0.310 & 0.249 & 0.311 \\
\hline
\end{tabular}


Table 4A. Bank market power and Islamic presence

This table displays the estimation results of Equation (2) for two sub-samples, Islamic banks (columns (1) to (3)) and conventional banks (columns (4) to (6)): Deposit rate De $_{i, t}=\alpha_{i}+\alpha_{t}+\beta_{1}$ Lerner $_{i, t}+\beta_{2}$ Islamic presence $_{j, t}+\beta_{3}$ Lerner $_{i, t} *$ Islamic presence $_{j, t}+\varphi X_{i, t-1}+\gamma Z_{j, t}+\varepsilon_{i, t}$ where Deposit rateit is our dependent variable, Lernerit, is our measure of banks' market power, $X_{\mathrm{it}-1}$ is a vector of one-year lagged bank-level variables and $Z_{j t}$ a vector of country-level variables. Islamic presence measures the strength of Islamic presence in country j. We use two different measures to capture the extent of Islamic presence:

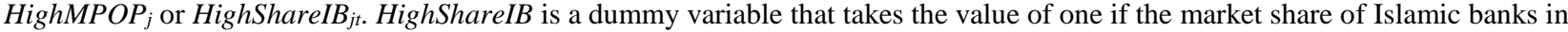
country $\mathrm{j}$ at time $\mathrm{t}$ is above the sample mean and zero otherwise. HighMPOP is a dummy variable that takes the value of one is the share of Muslim population in country $\mathrm{j}$ is above the sample mean and zero otherwise. In columns (1) and (3), we study the impact of HighShareIB and in columns (2) and (4) the impact of HighMPOP. See Table B1 for variable definitions. We employ the fixedeffect (FE) estimator with standard errors clustered at the bank level for estimations reported in columns (1) and (3). We employ Hausman-Taylor (HT) estimator with robust jackknife standard errors for estimations reported in columns (2) and (4).

\begin{tabular}{|c|c|c|c|c|}
\hline & \multicolumn{2}{|c|}{ Islamic banks } & \multicolumn{2}{|c|}{ Conventional banks } \\
\hline & $(1)$ & $(2)$ & $(3)$ & $(4)$ \\
\hline \multirow[t]{2}{*}{ Lerner } & $0.0356 * *$ & 0.0223 & $-0.0324 * * *$ & $-0.0213 * * *$ \\
\hline & $(2.05)$ & $(0.40)$ & $(-4.44)$ & $(-2.63)$ \\
\hline \multirow[t]{2}{*}{ HighShareIB } & $0.0265 * * *$ & & $0.0111 * * *$ & \\
\hline & $(3.69)$ & & $(3.82)$ & \\
\hline \multirow[t]{2}{*}{ Lerner x HighShareIB } & $-0.0532 * * *$ & & $-0.0146^{* *}$ & \\
\hline & $(-2.99)$ & & $(-1.98)$ & \\
\hline \multirow[t]{2}{*}{ HighMPOP } & & 0.0204 & & $0.0313 * * *$ \\
\hline & & $(1.18)$ & & $(7.24)$ \\
\hline \multirow[t]{2}{*}{ Lerner x HighMPOP } & & -0.0262 & & $-0.0418 * * *$ \\
\hline & & $(-0.44)$ & & $(-3.94)$ \\
\hline \multirow[t]{2}{*}{ ROE } & 0.0191 & $0.0268 *$ & 0.00722 & $0.0106^{*}$ \\
\hline & $(1.47)$ & $(1.75)$ & $(1.57)$ & $(1.94)$ \\
\hline \multirow[t]{2}{*}{ Liquidity } & 0.00552 & -0.00357 & $-0.0179 * *$ & -0.0112 \\
\hline & $(0.34)$ & $(-0.25)$ & $(-2.30)$ & $(-1.49)$ \\
\hline \multirow[t]{2}{*}{ LLR } & $0.106^{* *}$ & 0.124 & -0.0252 & $-0.0392 * *$ \\
\hline & $(2.03)$ & $(0.96)$ & $(-1.41)$ & $(-2.21)$ \\
\hline \multirow[t]{2}{*}{ Equity } & 0.0474 & 0.0514 & -0.0128 & -0.0281 \\
\hline & $(1.17)$ & $(0.76)$ & $(-0.44)$ & $(-1.03)$ \\
\hline \multirow[t]{2}{*}{ Size } & $0.0120 *$ & 0.00691 & $0.00868 * * *$ & $0.00434 * *$ \\
\hline & $(1.87)$ & $(1.06)$ & $(4.07)$ & $(2.53)$ \\
\hline \multirow[t]{2}{*}{ Listed } & $0.0445 * * *$ & 0.00493 & $0.0579 * * *$ & 0.0000928 \\
\hline & $(2.84)$ & $(1.16)$ & $(6.73)$ & $(0.08)$ \\
\hline \multirow[t]{2}{*}{ Inflation } & 0.0164 & 0.0267 & $0.0115^{* *}$ & $0.0151 * * *$ \\
\hline & (1.09) & $(1.52)$ & $(2.10)$ & $(2.70)$ \\
\hline \multirow[t]{2}{*}{ HHI } & 0.0897 & 0.0758 & $-0.0839 * * *$ & $-0.0525 * * *$ \\
\hline & $(1.41)$ & $(0.68)$ & $(-3.44)$ & $(-2.65)$ \\
\hline \multirow[t]{2}{*}{ GGDP } & -0.00683 & -0.00156 & -0.0160 & $-0.0280 * *$ \\
\hline & $(-0.32)$ & $(-0.05)$ & $(-1.23)$ & $(-2.20)$ \\
\hline \multirow[t]{2}{*}{ Constant } & $-0.191 *$ & -0.110 & $-0.0760 * *$ & -0.0188 \\
\hline & $(-1.84)$ & $(-0.90)$ & $(-2.21)$ & $(-0.69)$ \\
\hline Time effects & Yes & Yes & Yes & Yes \\
\hline N Obs. & 499 & 499 & 2257 & 2280 \\
\hline N Banks. & 96 & 96 & 379 & 380 \\
\hline R-Squared & 0.296 & & 0.327 & \\
\hline
\end{tabular}


Table 4B. Impact of Lerner and Islamic presence

Islamic banks

(1)

(2)

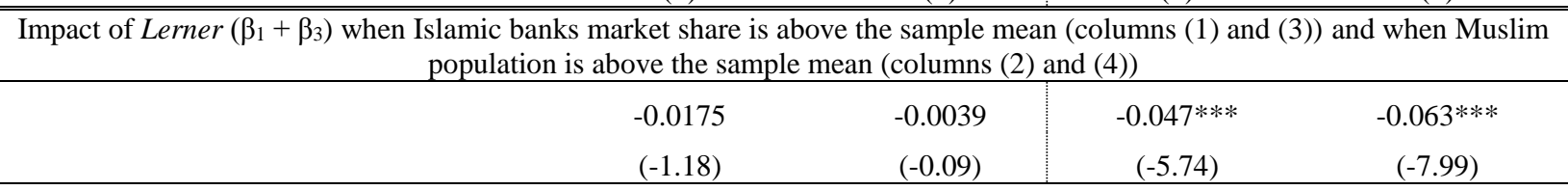

Impact of Islamic presence $\left(\beta_{2}+\beta_{3}\right)$ when Islamic banks market share is above the sample mean (columns (1) and (3)) and when Muslim population is above the sample mean (columns (2) and (4)) computed at different value of Lerner

\begin{tabular}{lcc:cc}
\hline $25^{\text {th }}$ percentile & $0.0196 * * *$ & 0.0169 & $0.0085^{* * *}$ & $0.0238^{* * *}$ \\
& $(3.38)$ & $(1.54)$ & $(4.23)$ & $(7.30)$ \\
$50^{\text {th }}$ percentile & $0.0142 * * *$ & 0.0143 & $0.007 * * *$ & $0.0196^{* * *}$ \\
& $(2.74)$ & $(1.75)$ & $(4.00)$ & $(6.44)$ \\
$75^{\text {th }}$ percentile & 0.0079 & 0.0111 & $0.006^{* * *}$ & $0.0167^{* * *}$ \\
& $(1.50)$ & $(1.14)$ & $(3.43)$ & $(5.37)$ \\
\hline \hline
\end{tabular}


Table 5. Market-level competition and banks' deposit rate

This table displays the estimation results of Equation (1) for two sub-samples, Islamic banks (columns (1) to (3)) and conventional banks (columns (4) to (6)): Deposit rate ritt $=\alpha_{i}+\alpha_{t}+\beta_{1}$ Lerner $_{i, t}+\varphi X_{i, t-1}+\gamma Z_{j, t}+\varepsilon_{i, t}$ where Deposit rate $_{i t}$ is our dependent variable, Lerner $j$ is a country-level measure of competition, $X_{\mathrm{it}-1}$ is a vector of one-year lagged banklevel variables and $Z_{j t}$ a vector of country-level variables. See Table B1 for variable definitions. This table reports the impact on IBs and CBs deposit rate respectively of competition, in the Islamic banking segment $\left(\right.$ LernerIB $\left._{j t}\right)$ (columns (1) and (4)), in the conventional banking segment (LernerCB $B_{j t}$ ) (columns (2) and (5)) and in the whole banking market (LernerMKT $\left.T_{j t}\right)$ (columns (3) and (6)). We employ the fixed-effect technique for our estimation. Standard errors are clustered at the bank level. Robust t-statistics are reported in parentheses. $* * *, * *$, and $*$ indicate significance at $1 \%, 5 \%$, and $10 \%$ respectively.

\begin{tabular}{|c|c|c|c|c|c|c|}
\hline & \multicolumn{3}{|c|}{ Islamic banks } & \multicolumn{3}{|c|}{ Conventional banks } \\
\hline & $(1)$ & (2) & (3) & (4) & (5) & $(6)$ \\
\hline \multirow[t]{2}{*}{ LernerIB } & -0.0270 & & & -0.00516 & & \\
\hline & $(-1.62)$ & & & $(-1.03)$ & & \\
\hline \multirow[t]{2}{*}{ LernerCB } & & -0.0376 & & & $-0.0421 * * *$ & \\
\hline & & $(-1.45)$ & & & $(-3.29)$ & \\
\hline \multirow[t]{2}{*}{ LernerMKT } & & & -0.0342 & & & $-0.0454 * * *$ \\
\hline & & & $(-1.63)$ & & & $(-3.87)$ \\
\hline \multirow[t]{2}{*}{ ROE } & $0.0310 * *$ & $0.0274 * *$ & $0.0286 * *$ & -0.00153 & 0.000947 & 0.00114 \\
\hline & $(2.30)$ & $(2.08)$ & $(2.17)$ & $(-0.32)$ & $(0.19)$ & $(0.23)$ \\
\hline \multirow[t]{2}{*}{ Liquidity } & 0.00389 & 0.00627 & 0.00444 & $-0.0177 * *$ & $-0.0158^{*}$ & $-0.0169 * *$ \\
\hline & $(0.30)$ & $(0.48)$ & $(0.33)$ & $(-2.02)$ & $(-1.90)$ & $(-2.07)$ \\
\hline \multirow[t]{2}{*}{ LLR } & $0.135 * *$ & $0.126^{* *}$ & $0.130 * *$ & -0.0182 & -0.0287 & -0.0271 \\
\hline & $(2.37)$ & $(2.03)$ & $(2.17)$ & $(-1.06)$ & $(-1.57)$ & $(-1.48)$ \\
\hline \multirow[t]{2}{*}{ Equity } & 0.0550 & 0.0627 & 0.0608 & -0.0105 & -0.0203 & -0.0195 \\
\hline & $(1.26)$ & $(1.41)$ & $(1.37)$ & $(-0.33)$ & $(-0.63)$ & $(-0.61)$ \\
\hline \multirow[t]{2}{*}{ Size } & $0.0118^{*}$ & $0.0123 *$ & $0.0121 *$ & $0.00917 * * *$ & $0.0105 * * *$ & $0.0106 * * *$ \\
\hline & $(1.93)$ & $(1.89)$ & $(1.87)$ & (3.91) & $(4.31)$ & $(4.32)$ \\
\hline \multirow[t]{2}{*}{ Listed } & 0.00186 & 0.0223 & 0.00195 & $0.0571 * * *$ & $0.0510 * * *$ & $0.0507 * * *$ \\
\hline & $(0.59)$ & $(1.58)$ & $(0.64)$ & (7.41) & (5.84) & (5.95) \\
\hline \multirow[t]{2}{*}{ Inflation } & 0.0110 & 0.0148 & 0.0129 & $0.0118^{*}$ & $0.0149 * *$ & $0.0140 * *$ \\
\hline & $(0.64)$ & $(0.88)$ & $(0.76)$ & $(1.75)$ & $(2.45)$ & $(2.29)$ \\
\hline \multirow[t]{2}{*}{ HHI } & 0.0929 & 0.0957 & 0.0976 & -0.0502 & -0.0335 & -0.0335 \\
\hline & $(1.23)$ & $(1.24)$ & $(1.30)$ & $(-1.58)$ & $(-1.16)$ & $(-1.15)$ \\
\hline \multirow[t]{2}{*}{ GGDP } & 0.00133 & 0.0134 & 0.00900 & $-0.0390 * * *$ & -0.0174 & -0.0182 \\
\hline & $(0.06)$ & $(0.56)$ & $(0.40)$ & $(-2.78)$ & $(-1.32)$ & $(-1.39)$ \\
\hline \multirow[t]{2}{*}{ Constant } & -0.166 & -0.170 & -0.168 & $-0.0924 * *$ & $-0.102 * *$ & $-0.103 * *$ \\
\hline & $(-1.59)$ & $(-1.51)$ & $(-1.51)$ & $(-2.51)$ & $(-2.49)$ & $(-2.52)$ \\
\hline Time effects & Yes & Yes & Yes & Yes & Yes & Yes \\
\hline N Obs. & 524 & 517 & 524 & 2278 & 2338 & 2338 \\
\hline N Banks. & 97 & 97 & 97 & 384 & 386 & 386 \\
\hline R-Squared & 0.236 & 0.232 & 0.234 & 0.270 & 0.257 & 0.258 \\
\hline
\end{tabular}


Table 6A. Islamic and conventional banking segment competition and Islamic presence

This table displays the estimation results of Equation (2) for two sub-samples, Islamic banks (columns (1) to (4)) and conventional banks (columns (5) to (8)): Deposit rate De $_{i, t}=\alpha_{i}+\alpha_{t}+\beta_{1}$ Lerner $_{i, t}+\beta_{2}{\text { Islamic presence }+\beta_{3} \text { Lerner }_{i, t} *}^{*}$ Islamic presence $_{j, t}+\varphi X_{i, t-1}+\gamma Z_{j, t}+\varepsilon_{i, t}$ where Deposit rate it $_{i t}$ is our dependent variable, Lerner $_{i t}$, is a country-level measure of competition, $X_{\mathrm{it}-1}$ is a vector of one-year lagged bank-level variables and $Z_{j t}$ a vector of country-level variables. Islamic presence measures the strength of Islamic presence in country j. We use two different measures to capture the extent of Islamic presence: HighMPOP $_{j}$ or HighShareIB ${ }_{j t}$. HighShareIB is a dummy variable that takes the value of one if the market share of Islamic banks in country $\mathrm{j}$ at time $\mathrm{t}$ is above the sample mean and zero otherwise. HighMPOP is a dummy variable that takes the value of one is the share of Muslim population in country $\mathrm{j}$ is above the sample mean and zero otherwise. Control: other control variables presented in section 2.1. See Table B1 for variable definitions.

This table reports the impact on IBs and CBs deposit rate respectively of competition, in the Islamic segment (LernerIB $\left.B_{j t}\right)$ (columns (1) and (2) and (5)) and (6)) and in the conventional segment (LernerCB $\left.B_{j t}\right)$ (columns (3) and (4) and (7) and (8)).

We employ the fixed-effect (FE) estimator with standard errors clustered at the bank level for estimations reported in columns (1), (3), (5) and (7). We employ Hausman-Taylor (HT) estimator with robust jackknife standard errors for estimations reported in columns (2), (4), (6) and (8). Robust $z$-statistics are reported in parentheses. ***, **, and * indicate significance at $1 \%, 5 \%$, and $10 \%$ respectively.

\begin{tabular}{|c|c|c|c|c|c|c|c|c|}
\hline & \multicolumn{4}{|c|}{ Islamic banks } & \multicolumn{4}{|c|}{ Conventional banks } \\
\hline & $(1)$ & (2) & (3) & (4) & $(5)$ & (6) & (7) & $(8)$ \\
\hline \multirow[t]{2}{*}{ LernerIB } & -0.0113 & -0.00896 & & & 0.00132 & 0.00118 & & \\
\hline & $(-0.47)$ & $(-0.51)$ & & & $(0.27)$ & $(0.21)$ & & \\
\hline \multirow[t]{2}{*}{ LernerIB x HighShareIB } & -0.0225 & & & & $-0.025 * * *$ & & & \\
\hline & $(-1.18)$ & & & & $(-3.04)$ & & & \\
\hline \multirow[t]{2}{*}{ LernerIB x HighMPOP } & & $-0.0590 * *$ & & & & $-0.039 * * *$ & & \\
\hline & & $(-2.33)$ & & & & $(-4.35)$ & & \\
\hline \multirow[t]{2}{*}{ LernerCB } & & & -0.0142 & $-0.0759 *$ & & & $-0.044 * * *$ & $-0.0312 * *$ \\
\hline & & & $(-0.41)$ & $(-1.97)$ & & & $(-3.21)$ & $(-2.24)$ \\
\hline \multirow[t]{2}{*}{ LernerCB x HighShareIB } & & & -0.0261 & & & & 0.00943 & \\
\hline & & & $(-0.96)$ & & & & $(0.71)$ & \\
\hline \multirow[t]{2}{*}{ LernerCB x HighMPOP } & & & & 0.0120 & & & & $-0.0358 * *$ \\
\hline & & & & $(0.25)$ & & & & $(-2.30)$ \\
\hline \multirow[t]{2}{*}{ HighShareIB } & $0.0152 *$ & & $0.0185^{*}$ & & $0.0164 * * *$ & & 0.00467 & \\
\hline & $(1.97)$ & & $(1.96)$ & & $(5.84)$ & & $(1.02)$ & \\
\hline \multirow[t]{2}{*}{ HighMPOP } & & $0.0337 * * *$ & & 0.00907 & & $0.0285 * * *$ & & $0.0310 * * *$ \\
\hline & & $(4.24)$ & & $(0.50)$ & & $(7.11)$ & & $(5.20)$ \\
\hline Control & Yes & Yes & Yes & Yes & Yes & Yes & Yes & Yes \\
\hline Time effects & Yes & Yes & Yes & Yes & Yes & Yes & Yes & Yes \\
\hline \multirow[t]{2}{*}{ Constant } & -0.152 & -0.0743 & -0.153 & -0.0724 & $-0.0927 * *$ & -0.0184 & $-0.0779 *$ & -0.0321 \\
\hline & $(-1.46)$ & $(-0.65)$ & $(-1.37)$ & $(-0.57)$ & $(-2.49)$ & $(-0.56)$ & $(-1.90)$ & $(-0.89)$ \\
\hline N Obs. & 524 & 524 & 517 & 517 & 2278 & 2278 & 2312 & 2338 \\
\hline N Banks. & 97 & 97 & 97 & 97 & 384 & 384 & 385 & 386 \\
\hline R-Squared & 0.249 & & 0.246 & & 0.280 & & 0.269 & \\
\hline
\end{tabular}


Table 6B. The impact of Lerner and Islamic presence

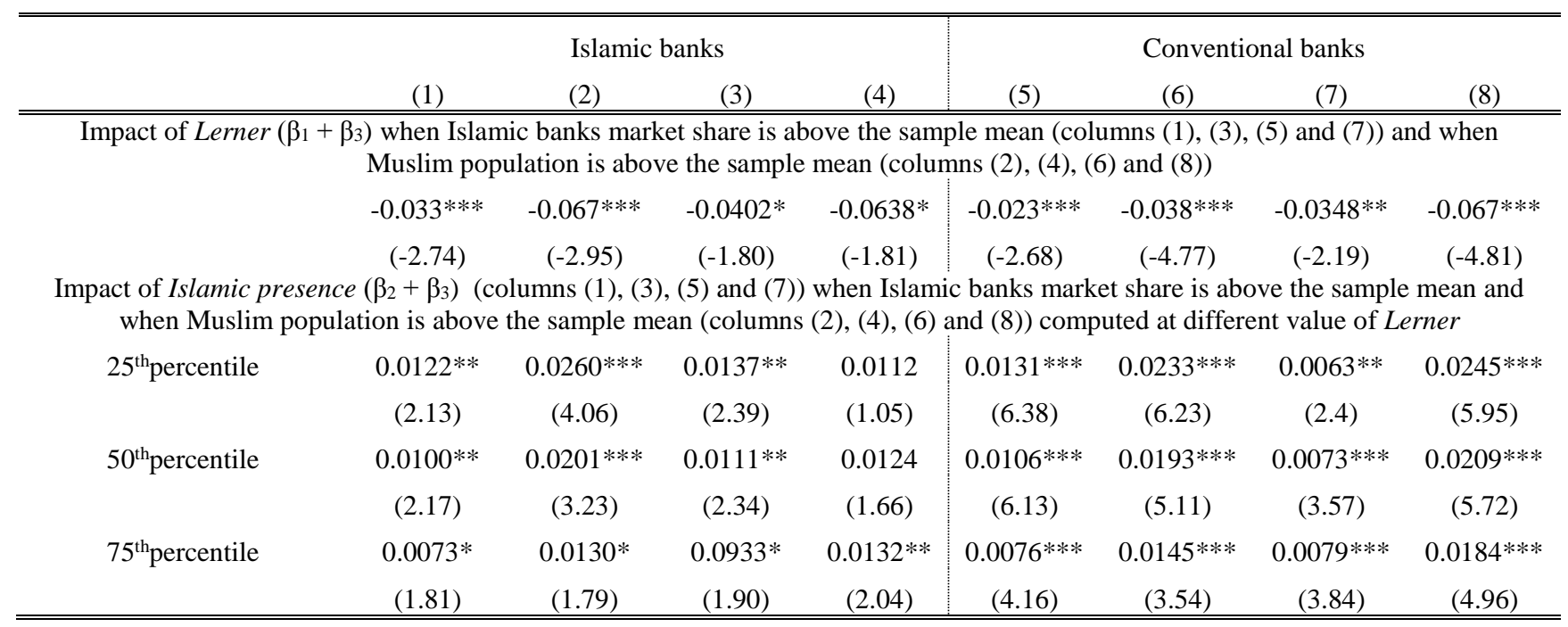


Table 7. Impact of the Global Financial Crisis (2007-2008)

This table displays the estimation results of Equation (3) for two sub-samples, Islamic banks (column (1)) and conventional banks (column (2)):

Deposit rate $_{j, t}=\alpha_{i}+\alpha_{t}+\beta_{1}$ Lerner $_{i, t}+\beta_{2}$ Crisis $_{j, t}+\beta_{3}$ Lerner $_{i, t} *$ Crisis $_{j, t}+\varphi X_{i, t-1}+\gamma Z_{j, t}+\varepsilon_{i, t}$

where Deposit rate ${ }_{i t}$ is our dependent variable, Lerner $i$, is our measure of banks' market power, Crisis is a dummy variable which equals one during the financial crisis period (2007 and 2008) and zero otherwise. $X_{\text {it- } 1}$ is a vector of one-year lagged bank-level variables and $Z_{j t}$ a vector of country-level variables. See Table B1 for variable definitions.

We employ the fixed-effect (FE) estimator with standard errors clustered at the bank-level. Robust Z-statistics are reported in parentheses. $* * *, * *$, and $*$ indicate significance at $1 \%, 5 \%$, and $10 \%$ respectively.

\begin{tabular}{|c|c|c|}
\hline & $\begin{array}{c}\text { Islamic banks } \\
\text { (1) } \\
\end{array}$ & $\begin{array}{c}\text { Conventional banks } \\
\text { (2) } \\
\end{array}$ \\
\hline Lerner & $\begin{array}{r}0.0129 \\
(0.66)\end{array}$ & $\begin{array}{c}-0.0355^{* * *} \\
(-4.99)\end{array}$ \\
\hline Crisis & $\begin{array}{l}-0.0140 \\
(-1.03)\end{array}$ & $\begin{array}{c}-0.0164 * * * \\
(-2.75)\end{array}$ \\
\hline Lerner x Crisis & $\begin{array}{c}-0.00849 \\
(-0.84)\end{array}$ & $\begin{array}{c}-0.0184^{*} \\
(-1.96)\end{array}$ \\
\hline ROE & $\begin{array}{c}0.0225^{*} \\
(1.70)\end{array}$ & $\begin{array}{c}0.00785 \\
(1.53)\end{array}$ \\
\hline Liquidity & $\begin{array}{c}0.0000991 \\
(0.01)\end{array}$ & $\begin{array}{c}-0.0140^{*} \\
(-1.85)\end{array}$ \\
\hline LLR & $\begin{array}{l}0.121^{*} \\
(1.83)\end{array}$ & $\begin{array}{l}-0.0291 \\
(-1.61)\end{array}$ \\
\hline Equity & $\begin{array}{l}0.0623 \\
(1.34)\end{array}$ & $\begin{array}{l}-0.0150 \\
(-0.50)\end{array}$ \\
\hline Size & $\begin{array}{c}0.0132 * * \\
(2.06)\end{array}$ & $\begin{array}{c}0.00931 * * * \\
\quad(4.36)\end{array}$ \\
\hline Listed & $\begin{array}{c}0.0437 * * * \\
(2.75)\end{array}$ & $\begin{array}{c}0.0521 * * * \\
(6.87)\end{array}$ \\
\hline Inflation & $\begin{array}{c}0.0322 * \\
(1.86)\end{array}$ & $\begin{array}{c}0.0213 * * * \\
(3.76)\end{array}$ \\
\hline HHI & $\begin{array}{l}0.0907 \\
(1.23)\end{array}$ & $\begin{array}{c}-0.0434^{*} \\
(-1.89)\end{array}$ \\
\hline GGDP & $\begin{array}{l}-0.0105 \\
(-0.45)\end{array}$ & $\begin{array}{c}-0.0254 * * \\
(-2.09)\end{array}$ \\
\hline Constant & $\begin{array}{l}-0.197 * \\
(-1.83)\end{array}$ & $\begin{array}{c}-0.0883^{* *} \\
(-2.53)\end{array}$ \\
\hline Time effects & Yes & Yes \\
\hline N Obs & 499 & 2280 \\
\hline N Banks & 96 & 380 \\
\hline R-squared & 0.249 & 0.316 \\
\hline Impact of Lerner during the crisis period $\left(\beta_{1}+\beta_{3}\right)$ & $\begin{array}{c}0.0044 \\
(0.20)\end{array}$ & $\begin{array}{c}-0.0539 * * * \\
(-4.19)\end{array}$ \\
\hline
\end{tabular}


Table 8. Reaction of Islamic and conventional banks to competitive conditions in the other market segment

This table displays the estimation results of Equations (4) and (5) for two sub-samples, Islamic banks (column (1)) and conventional banks (column (2)):

$$
\begin{aligned}
\text { Depositrate }_{j, t}^{I B}= & \alpha_{i}+\alpha_{t}+\beta_{1} \text { Lerner }_{j, t}^{I B}+\beta_{2} \text { HighLernerCB }_{j, t}+\beta_{3} \text { Lerner }_{j, t}^{I B} * \text { HighLernerCB }_{j, t}+\varphi X_{i, t-1}+\gamma Z_{j, t} \\
& +\varepsilon_{i, t} \\
\text { Deposit rate }_{j, t}^{C B}= & \alpha_{i}+\alpha_{t}+\beta_{1} \text { Lerner }_{j, t}^{C B}+\beta_{2} \text { HighLernerIB }_{j, t}+\beta_{3} \text { Lerner }_{j, t}^{C B} * \text { HighLernerIB }_{j, t}+\varphi X_{i, t-1}+\gamma Z_{j, t} \\
& +\varepsilon_{i, t}
\end{aligned}
$$

where Deposit rate ${ }^{I B}{ }_{i t}$ is the deposit rate of Islamic banks, Deposit rate ${ }^{C B_{i t}}$ is the deposit rate of conventional banks, LernerIB $B_{j t}$ is a measure of competition in the Islamic banks' market, Lerner $C B_{j t}$ is a measure of competition in the conventional banks' market, $X_{\text {it-1 }}$ is a vector of one-year lagged bank-level variables and $Z_{j t}$ a vector of country-level variables. HighLernerIB $B_{j t}$ is a dummy variable that takes the value of one if the value of LernerIBjt in country $\mathrm{j}$ at time $\mathrm{t}$ is above the sample mean and zero otherwise. HighLernerC $B_{j t}$ is a dummy variable that takes the value of one if the value of LernerC $B_{j t}$ in country $\mathrm{j}$ at time $\mathrm{t}$ is above the sample mean and zero otherwise. Control: other control variables presented in section 2.1. See Table B1 for variable

\begin{tabular}{|c|c|c|}
\hline & $\begin{array}{c}\text { Islamic banks } \\
\text { (1) } \\
\end{array}$ & $\begin{array}{c}\text { Conventional banks } \\
\text { (2) } \\
\end{array}$ \\
\hline LernerIB & $\begin{array}{l}-0.0205 \\
(-0.99)\end{array}$ & \\
\hline HighLernerCB & $\begin{array}{c}-0.00441 \\
(-1.00)\end{array}$ & \\
\hline LernerIB x HighLernerCB & $\begin{array}{c}-0.00734 \\
(-0.38)\end{array}$ & \\
\hline LernerCB & & $\begin{array}{c}-0.0447 * * * \\
(-3.05)\end{array}$ \\
\hline HighLernerIB & & $\begin{array}{c}-0.0106 * * * \\
(-3.06)\end{array}$ \\
\hline LernerCB x HighLernerIB & & $\begin{array}{c}0.0313^{* * * *} \\
(3.04)\end{array}$ \\
\hline Constant & $\begin{array}{l}-0.155 \\
(-1.49)\end{array}$ & $\begin{array}{c}-0.0881 * * \\
(-2.16)\end{array}$ \\
\hline Controls & Yes & Yes \\
\hline Time effects & Yes & Yes \\
\hline N Obs. & 517 & 2278 \\
\hline N Banks & 97 & 384 \\
\hline \multicolumn{3}{|c|}{$\begin{array}{l}\text { Impact of Lerner }\left(\beta_{1}+\beta_{2}\right) \text { when the competition in the conventional banking } \\
\text { segment is low (column (1)) and when the competition in the Islamic } \\
\text { banking segment is low (column (2)) }\end{array}$} \\
\hline & $\begin{array}{l}-0.0278 \\
(-1.42)\end{array}$ & $\begin{array}{c}-0.01337 \\
(-0.78)\end{array}$ \\
\hline
\end{tabular}
definitions.

We employ the fixed-effect (FE) estimator with standard errors clustered at the bank-level. Robust z-statistics are reported in parentheses. $* * *, * *$, and $*$ indicate significance at $1 \%, 5 \%$, and $10 \%$ respectively. 
This table displays the estimation results of Equations (1) and (2) for two sub-samples, Islamic banks (columns (1) to (3)) and conventional banks (columns (4) to (6)), when we replace inflation by market (short-term) interest rates:

Deposit rate $_{i, t}=\alpha_{i}+\alpha_{t}+\beta_{1}$ Lerner $_{i, t}+\varphi X_{i, t-1}+\gamma Z_{j, t}+\varepsilon_{i, t}$

Deposit rate $_{i, t}=\alpha_{i}+\alpha_{t}+\beta_{1}$ Lerner $_{i, t}+\beta_{2}$ Islamic presence $_{j, t}+\beta_{3}$ Lerner $_{i, t} *$ Islamic presence $_{j, t}+\varphi X_{i, t-1}$

$$
+\gamma Z_{j, t}+\varepsilon_{i, t}
$$

where Deposit rate it is our dependent variable, Lerner $i$, is our measure of banks' market power, $X_{\text {it-1 }}$ is a vector of one-year lagged bank-level variables and $Z_{j t}$ a vector of country-level variables. Islamic presence measures the strength of Islamic presence in country j. We use two different measures to capture the extent of Islamic presence: HighMPOP $j$ or HighShareIBjt. HighShareIB is a dummy variable that takes the value of one if the market share of Islamic banks in country $\mathrm{j}$ at time $\mathrm{t}$ is above the sample mean and zero otherwise. HighMPOP is a dummy variable that takes the value of one is the share of Muslim population in country $\mathrm{j}$ is above the sample mean and zero otherwise. In columns (2) and (5), we study the impact of HighShareIB and in columns (3) and (6) the impact of HighMPOP. Control: other control variables presented in section 2.1. See Table B1 for variable definitions.

We employ the fixed-effect (FE) estimator with standard errors clustered at the bank level for estimations reported in columns (1), (2), (4) and (5). We employ Hausman-Taylor (HT) with robust jackknife standard errors for estimations reported in columns (3) and (6). Robust z-statistics are reported in parentheses. ***, **, and * indicate significance at 1\%, 5\%, and 10\% respectively.

\begin{tabular}{|c|c|c|c|c|c|c|}
\hline & \multicolumn{3}{|c|}{ Islamic banks } & \multicolumn{3}{|c|}{ Conventional banks } \\
\hline & $(1)$ & $(2)$ & (3) & (4) & $(5)$ & $(6)$ \\
\hline \multirow[t]{2}{*}{ Lerner } & 0.0207 & 0.0298 & 0.0454 & $-0.0325 * * *$ & $-0.0303 * * *$ & $-0.0219 * * *$ \\
\hline & $(1.11)$ & $(1.64)$ & $(0.79)$ & $(-4.65)$ & $(-4.21)$ & $(-2.61)$ \\
\hline \multirow[t]{2}{*}{ HighShareIB } & & $0.0126^{* * *}$ & & & 0.00205 & \\
\hline & & $(2.84)$ & & & $(0.78)$ & \\
\hline \multirow[t]{2}{*}{ Lerner x HighShareIB } & & $-0.0284 *$ & & & $-0.0149 * *$ & \\
\hline & & $(-1.98)$ & & & $(-2.00)$ & \\
\hline \multirow[t]{2}{*}{ HighMPOP } & & & 0.00691 & & & 0.00726 \\
\hline & & & $(0.42)$ & & & $(1.63)$ \\
\hline \multirow[t]{2}{*}{ Lerner x HighMPOP } & & & -0.0460 & & & $-0.0264 * *$ \\
\hline & & & $(-0.81)$ & & & $(-2.51)$ \\
\hline \multirow[t]{2}{*}{ Interest } & $0.00304 * * *$ & $0.00280 * * *$ & $0.00308 * * *$ & $0.00404 * * *$ & $0.00408 * * *$ & $0.00381 * * *$ \\
\hline & $(5.44)$ & $(5.17)$ & $(4.54)$ & (11.35) & $(11.27)$ & $(12.87)$ \\
\hline \multirow[t]{2}{*}{ Constant } & -0.102 & -0.104 & -0.0389 & 0.0287 & 0.0298 & $0.0470 * * *$ \\
\hline & $(-1.16)$ & $(-1.18)$ & $(-0.53)$ & $(1.23)$ & $(1.27)$ & $(2.97)$ \\
\hline Control & Yes & Yes & Yes & Yes & Yes & Yes \\
\hline Time effects & Yes & Yes & Yes & Yes & Yes & Yes \\
\hline N Obs. & 438 & 438 & 438 & 2098 & 2072 & 2098 \\
\hline N Banks & 81 & 81 & 81 & 363 & 361 & 363 \\
\hline R-squared & 0.260 & 0.279 & & 0.356 & 0.359 & \\
\hline
\end{tabular}




\begin{tabular}{ll|c} 
Islamic banks & Conventional banks \\
$(1)$ & (2) & (3) \\
\hline
\end{tabular}

(4)

Impact of Lerner $\left(\beta_{1}+\beta_{3}\right)$ when Islamic banks market share is above the sample mean (columns (1) and (3)) and when Muslim population is above the sample mean (columns (2) and (4))

\begin{tabular}{cc|cc}
0.0014 & -0.0005 & $0.04522 * * *$ & $-0.0482 * * *$ \\
$(0.09)$ & $(-0.01)$ & $(-5.55)$ & $(-6.41)$
\end{tabular}

Impact of Islamic presence $\left(\beta_{2}+\beta_{3}\right)$ (columns (1) and (3)) when Islamic banks market share is above the sample mean and when Muslim population is above the sample mean (columns (2) and (4)) computed at different value of Lerner

$25^{\text {th }}$ percentile

0.0086

0.00047

$-0.0007$

0.0022

$50^{\text {th }}$ percentile

(0.04)

$(-0.49)$

0.00576

$-0.0041$

$-0.0021$

$-0.0001$

$(1.41)$

(-0.46)

$(-1.53)$

$(-0.04)$

$75^{\text {th }}$ percentile

0.0029

$-0.0087$

$-0.0033^{* *}$

$-0.0022$

(0.62)

$(-0.82)$

$(-2.29)$

$(-0.68)$ 
Table 10A. Robustness: Alternative measure of PLS

This table displays the estimation results of Equation (1) and (2) for two sub-samples, Islamic banks (column (1), (2), and (3)) and conventional banks (column (4), (5), and (6)) when replacing ROE by ROA:

$$
\begin{aligned}
\text { Deposit rate }_{i, t}= & \alpha_{i}+\alpha_{t}+\beta_{1} \text { Lerner }_{i, t}+\varphi X_{i, t-1}+\gamma Z_{j, t}+\varepsilon_{i, t} \\
\text { Deposit rate }_{i, t}= & \alpha_{i}+\alpha_{t}+\beta_{1} \text { Lerner }_{i, t}+\beta_{2} \text { Islamic presence }_{j, t}+\beta_{3} \text { Lerner }_{i, t} * \text { Islamic presence }_{j, t}+\varphi X_{i, t-1} \\
& +\gamma Z_{j, t}+\varepsilon_{i, t}
\end{aligned}
$$

where Deposit rate it $_{\text {is }}$ our dependent variable, Lerner $_{i t}$, is our measure of banks' market power, $X_{\mathrm{it}-1}$ is a vector of one-year lagged bank-level variables and $Z_{j t}$ a vector of country-level variables. Islamic presence measures the strength of Islamic presence in country j. We use two different measures to capture the extent of Islamic presence: HighMPOP $j$ or HighShareIBjt. HighShareIB is a dummy variable that takes the value of one if the market share of Islamic banks in country $\mathrm{j}$ at time $\mathrm{t}$ is above the sample mean and zero otherwise. HighMPOP is a dummy variable that takes the value of one is the share of Muslim population in country $\mathrm{j}$ is above the sample mean and zero otherwise. In columns (2) and (5), we study the impact of HighShareIB and in columns (3) and (6) the impact of HighMPOP. Control: other control variables presented in section 2.1. See Table B1 for variable definitions.

We employ the fixed-effect (FE) estimator with standard errors clustered at the bank level for estimations reported in columns (1), (2), (4) and (5). We employ Hausman-Taylor (HT) estimator with robust jackknife standard errors for estimations reported

\begin{tabular}{|c|c|c|c|c|c|c|}
\hline & \multicolumn{3}{|c|}{ Islamic banks } & \multicolumn{3}{|c|}{ Conventional banks } \\
\hline & $(1)$ & $(2)$ & (3) & (4) & $(5)$ & $(6)$ \\
\hline \multirow[t]{2}{*}{ Lerner } & 0.00554 & 0.0172 & 0.0128 & $-0.0381 * * *$ & $-0.0359 * * *$ & $-0.0210 * * *$ \\
\hline & $(0.30)$ & $(0.94)$ & $(0.26)$ & $(-5.23)$ & $(-4.94)$ & $(-2.59)$ \\
\hline \multirow[t]{2}{*}{ HighShareIB } & \multicolumn{3}{|c|}{$0.0166^{* * *}$} & \multicolumn{3}{|c|}{$0.00609 * * *$} \\
\hline & \multicolumn{3}{|c|}{ (3.08) } & \multicolumn{3}{|c|}{$(2.64)$} \\
\hline \multirow[t]{2}{*}{ Lerner x HighShareIB } & \multicolumn{3}{|c|}{$-0.0305 * *$} & \multicolumn{3}{|c|}{-0.00288} \\
\hline & \multicolumn{3}{|c|}{$(-2.22)$} & & $(-0.44)$ & \\
\hline \multirow[t]{2}{*}{ HighMPOP } & & & 0.0183 & & & $0.0316 * * *$ \\
\hline & & & $(1.14)$ & & & $(7.16)$ \\
\hline \multirow[t]{2}{*}{ Lerner x HighMPOP } & & & -0.0206 & & & $-0.0422 * * *$ \\
\hline & & & $(-0.36)$ & & & $(-3.86)$ \\
\hline \multirow[t]{2}{*}{ ROA } & $0.300 * * *$ & $0.262 * *$ & $0.303 * *$ & 0.0379 & 0.0262 & $0.0749 *$ \\
\hline & $(2.87)$ & $(2.55)$ & $(2.42)$ & $(0.85)$ & $(0.60)$ & $(1.72)$ \\
\hline \multirow[t]{2}{*}{ Constant } & $-0.184 *$ & $-0.181 *$ & -0.101 & $-0.0949 * * *$ & $-0.0773 * *$ & -0.0208 \\
\hline & $(-1.68)$ & $(-1.71)$ & $(-0.81)$ & $(-2.70)$ & $(-2.27)$ & $(-0.76)$ \\
\hline Control & Yes & Yes & Yes & Yes & Yes & Yes \\
\hline Time effects & Yes & Yes & Yes & Yes & Yes & Yes \\
\hline N Obs & 499 & 499 & 499 & 2280 & 2257 & 2280 \\
\hline N Banks & 96 & 96 & 96 & 380 & 379 & 380 \\
\hline R-squared & 0.267 & 0.295 & & 0.310 & 0.324 & \\
\hline
\end{tabular}
in columns (3) and (6). Robust z-statistics are reported in parentheses. ***, **, and * indicate significance at 1\%, 5\%, and 10\% respectively. 
Table 10B. The impact of Lerner and Islamic presence

\begin{tabular}{|c|c|c|c|c|}
\hline & \multicolumn{2}{|c|}{ Islamic banks } & \multicolumn{2}{|c|}{ Conventional banks } \\
\hline & $(1)$ & (2) & (3) & (4) \\
\hline \multicolumn{5}{|c|}{$\begin{array}{l}\text { Impact of Lerner }\left(\beta_{1}+\beta_{3}\right) \text { when Islamic banks market share is above the sample mean (columns (1) and (3)) and when Muslim } \\
\text { population is above the sample mean (columns (2) and (4)) }\end{array}$} \\
\hline & -0.0132 & -0.0078 & $-0.0387 * * *$ & $-0.0631 * * *$ \\
\hline & $(-0.98)$ & $(-0.17)$ & $(-4.37)$ & $(-7.4)$ \\
\hline \multicolumn{5}{|c|}{$\begin{array}{l}\text { Impact of Islamic presence }\left(\beta_{2}+\beta_{3}\right) \text { (columns (1) and (3)) when Islamic banks market share is above the sample mean and } \\
\text { when Muslim population is above the sample mean (columns (2) and (4)) computed at different value of Lerner }\end{array}$} \\
\hline \multirow[t]{2}{*}{$25^{\text {th }}$ percentile } & $0.0123 * * *$ & 0.0154 & $0.0055^{* * *}$ & $0.0235 * * *$ \\
\hline & $(2.67)$ & $(1.56)$ & $(3.18)$ & $(7.22)$ \\
\hline \multirow[t]{2}{*}{$50^{\text {th }}$ percentile } & $0.0092 * *$ & 0.01335 & $0.0052 * * *$ & $0.0197 * * *$ \\
\hline & $(2.06)$ & (1.69) & $(3.05)$ & $(6.42)$ \\
\hline \multirow[t]{2}{*}{$75^{\text {th }}$ percentile } & 0.0062 & 0.0112 & $0.0050 * * *$ & $0.0163 * * *$ \\
\hline & $(1.29)$ & $(1.18)$ & $(2.68)$ & $(5.17)$ \\
\hline
\end{tabular}


Table 11. Robustness: instrumental variable regression

This table displays the estimation results of Equations (1) and (2) for two sub-samples, Islamic banks (columns (1) and (2)) and conventional banks (columns (3) and (4)):

Deposit rate $_{i, t}=\alpha_{i}+\alpha_{t}+\beta_{1}$ Lerner $_{i, t}+\varphi X_{i, t-1}+\gamma Z_{j, t}+\varepsilon_{i, t}$

Deposit rate $_{i, t}=\alpha_{i}+\alpha_{t}+\beta_{1}$ Lerner $_{i, t}+\beta_{2}$ HighShareIB $_{j, t}+\beta_{3}$ Lerner $_{i, t} *$ HighShareIB $_{j, t}+\varphi X_{i, t-1}+\gamma Z_{j, t}+\varepsilon_{i, t}$ where Deposit rate ${ }_{i t}$ is our dependent variable, Lerner $_{i t}$, is our measure of banks' market power, $X_{\text {it }-1}$ is a vector of one-year lagged bank-level variables and $Z_{j t}$ a vector of country-level variables. $R O E_{i t-l}$ is considered as endogenous. We instrument $X_{\mathrm{it}-1}$ by $\mathrm{ROE}_{i t-2}$, ROE Industry, and market development (the ratio of stock market capitalization to GDP per capita). HighShareIB is a dummy variable that takes the value of one if the market share of Islamic banks in country $j$ at time $t$ is above the sample mean and zero otherwise. See Table B1 for variable definitions. We conduct our regressions using the instrumental variables technique. We report the Hansen J-Statistics for the validity of our instruments and the Kleinbergen-Paap wald FStatistics for the strength of our instruments. Standard errors are clustered at the bank level. Robust t-statistics are reported in parentheses. $* * *, * *$, and $*$ indicate significance at $1 \%, 5 \%$, and $10 \%$ respectively.

\begin{tabular}{|c|c|c|c|c|}
\hline & \multicolumn{2}{|c|}{ Islamic banks } & \multicolumn{2}{|c|}{ Conventional banks } \\
\hline & $(1)$ & $(2)$ & (3) & (4) \\
\hline \multirow[t]{2}{*}{ Lerner } & 0.0106 & 0.0235 & $-0.0487 * * *$ & $-0.0441 * * *$ \\
\hline & $(0.66)$ & $(1.30)$ & $(-6.43)$ & $(-5.30)$ \\
\hline \multirow[t]{2}{*}{ HighShareIB } & & $0.0168 * * *$ & & $0.00728 * *$ \\
\hline & & $(3.84)$ & & $(2.47)$ \\
\hline \multirow[t]{2}{*}{ Lerner x HighShareIB } & & $-0.0440 * * *$ & & -0.00812 \\
\hline & & $(-3.13)$ & & $(-1.07)$ \\
\hline \multirow[t]{2}{*}{ ROE } & 0.0118 & 0.0315 & $0.0547 * * *$ & $0.0516^{* * *}$ \\
\hline & $(0.39)$ & $(1.10)$ & $(4.30)$ & (4.09) \\
\hline \multirow[t]{2}{*}{ Liquidity } & 0.00738 & 0.00749 & $-0.0170 * *$ & $-0.0201 * * *$ \\
\hline & $(0.56)$ & $(0.54)$ & $(-2.56)$ & $(-3.02)$ \\
\hline \multirow[t]{2}{*}{ LLR } & $0.0804 * *$ & $0.0876 * *$ & -0.00704 & -0.00387 \\
\hline & $(2.17)$ & $(2.52)$ & $(-0.36)$ & $(-0.20)$ \\
\hline \multirow[t]{2}{*}{ Equity } & $0.0841 * *$ & $0.0816^{* *}$ & -0.0413 & $-0.0440 *$ \\
\hline & $(2.28)$ & $(2.42)$ & $(-1.63)$ & $(-1.74)$ \\
\hline \multirow[t]{2}{*}{ Size } & $0.0162 * * *$ & $0.0124 * *$ & $0.00806 * * *$ & $0.00779 * * *$ \\
\hline & $(2.98)$ & $(2.33)$ & (4.59) & $(4.39)$ \\
\hline \multirow[t]{2}{*}{ Listed } & $0.0258 *$ & 0.0207 & $0.0248 * * *$ & $0.0308 * * *$ \\
\hline & $(1.70)$ & $(1.34)$ & $(5.55)$ & $(6.00)$ \\
\hline \multirow[t]{2}{*}{ Inflation } & $0.0441 * * *$ & $0.0280 * *$ & $0.0206^{* * *}$ & $0.0147 * *$ \\
\hline & $(2.91)$ & $(2.11)$ & $(2.93)$ & $(2.16)$ \\
\hline \multirow[t]{2}{*}{ HHI } & $0.254 * * *$ & $0.260 * * *$ & -0.0316 & $-0.0770 * * *$ \\
\hline & $(3.64)$ & $(3.83)$ & $(-1.60)$ & $(-4.01)$ \\
\hline \multirow[t]{2}{*}{ GGDP } & -0.0359 & -0.0322 & $-0.0238 * *$ & $-0.0199 *$ \\
\hline & $(-1.26)$ & $(-1.14)$ & $(-2.05)$ & $(-1.78)$ \\
\hline N Obs & 413 & 413 & 2063 & 2041 \\
\hline N Banks & 71 & 71 & 319 & 318 \\
\hline R-squared & 0.361 & 0.396 & 0.247 & 0.266 \\
\hline Hansen J stat (chi-sq.) & 0.683 & 0.09 & 3.173 & 4.577 \\
\hline Hansen J stat (p-value) & 0.7106 & 0.9561 & 0.2046 & 0.1014 \\
\hline $\mathrm{KP}$ wald F stat & $8.375^{* * *}$ & $12.743 * * *$ & $27.722 * * *$ & $27.946 * * *$ \\
\hline \multicolumn{5}{|c|}{ Impact of Lerner $\left(\beta_{1}+\beta_{3}\right)$ when Islamic bank market share is above the sample mean } \\
\hline & & -0.0205 & & $-0.0522 * * *$ \\
\hline & & $(-1.79)$ & & $(-6.38)$ \\
\hline
\end{tabular}


